\title{
Schizothyriaceae
}

\section{Phookamsak $R^{1,2,3,4}$ Boonmee $S^{2}$ Norphanphoun $C^{1,2}$ Wanasinghe $D^{1,2}$ de

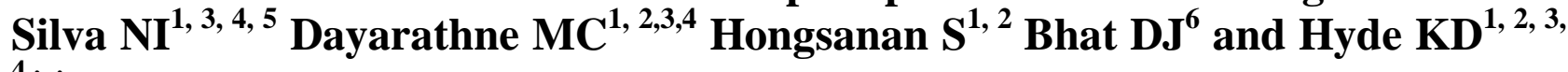 $\mathbf{4}_{* *}$}

${ }^{1}$ School of Science, Mae Fah Luang University, Chiang Rai, 57100, Thailand

${ }^{2}$ Center of Excellence in Fungal Research, Mae Fah Luang University, Chiang Rai, 57100 Thailand

${ }^{3}$ Key Laboratory for Plant Diversity and Biogeography of East Asia, Kunming Institute of Botany, Chinese Academy of Science, Kunming 650201, Yunnan, China

${ }^{4}$ World Agroforestry Centre East and Central Asia Office, 132 Lanhei Road, Kunming, 650201, Yunnan, China

${ }^{5}$ Department of Biology, Faculty of Science, Chiang Mai University, Chiang Mai, 50200 Thailand

${ }^{6}$ Formerly Department of Botany, Goa University, Goa, India; No. 128/1-J, Azad Housing Society, Curca, Goa Velha, India

Phookamsak R, Boonmee S, Norphanphoun C, Wanasinghe DN, de Silva NI, Dayarathne MC, Hongsanan S, Bhat DJ, Hyde KD - Schizothyriaceae. Mycosphere 7(2), 154-189, Doi 10.5943/mycosphere/7/2/7

\begin{abstract}
Schizothyriaceae is a poorly understood family which was introduced to accommodate epiphytes belonging to the class Dothideomycetes. Sixteen sexual and asexual genera have at various times been accommodated in Schizothyriaceae. However, modern taxonomic descriptions, molecular data and phylogenetic investigation of the genera in this family are limited. We therefore revisit the genera in Schizothyriaceae by loaning and examining the type and other specimens from herbaria worldwide. Circumscriptions of the genera previously placed in Schizothyriaceae are provided with illustrations and their higher level placements are determined based on modern descriptions. Based on morphology, we currently accept Hexagonella, Lecideopsella, Mycerema, Plochmopeltis and Schizothyrium in Schizothyriaceae. Kerniomyces, Metathyriella and Myriangiella are treated in Schizothyriaceae, genera incertae sedis, while Chaetoplaca is transferred to Ascomycetes, genera incertae sedis. Neopeltella is excluded from Schizothyriaceae, based on its thyriothecial ascomata and tentatively placed in Micropeltidaceae. Henningsiella is placed in Saccardiaceae due to its discoid ascomata. Linopeltis and Orthobellus are tentatively treated in Dothideomycetes, genera incertae sedis. Hysteropeltella which has elongate apothecial or hypothecia-like ascomata, is placed in Patellariaceae due to its similar morphology with Baggea. Mendogia is transferred to the family Myriangiaceae based on a morphologically similar specimen which is phylogenetically placed in Myriangiaceae. The hyphomycetous, Zygophiala is reported as the asexual morph of Schizothyrium. Hence, the genus is currently treated as a synonym of Schizothyrium. Nevertheless, representative species of the genera in Schizothyriaceae, including the type species, need to be recollected and sequenced to clarify the natural placement in Schizothyriaceae.
\end{abstract}

Keywords - asexual morph - epifoliar fungi - epiphytic fungi - Schizothyrium - taxonomy 


\section{Introduction}

Schizothyriaceae is a poorly understood family in the class Dothideomycetes, which comprises 16 genera and approximately 94 species (von Arx \& Müller 1975, Eriksson 1981, Batzer et al. 2008, Kirk et al. 2008, Crous et al. 2009, Hyde et al. 2013, Wijayawardene et al. 2014, Index Fungorum 2016). The family contains various sexual genera with ambiguous morphological characters, comprising two types of ascomata, viz. membranous and thyriothecial (Hyde at al. 2013). The genera in Schizothyriaceae have been reported as epiphytic, pathogenic or saprobic on various plants (von Arx \& Müller 1975, Batzer et al. 2008, Crous et al. 2009, Hyde et al. 2013, Farr \& Rossman 2015). Some genera cause disease on economic crops, such as Zygophiala, the putative asexual morph of Schizothyrium. These taxa cause the sooty blotch and flyspeck (SBFS) of apple and pear fruits (Batzer et al. 2005, 2008, Gao et al. 2014).

Schizothyriaceae was introduced by Saccardo (1928) as "Schizothyrieae" based on von Höhnel (1917) to accommodate epiphytic fungi and was originally described as "exciple depressed on cuticle, superficial, membranous, irregular fringed when mature" (Saccardo 1928). Five genera were initially included viz. Clypeolum, Mycrothyriella, Polyclypeolum, Phragmothyriella and the generic type Schizothyrium (Saccardo 1928, Hyde et al. 2013). Müller and von Arx (1962) circumscribed the taxonomy of didymosporous pyrenomycetes and treated 10 genera in Schizothyriaceae viz. Allosoma, Chaetoplaca, Chaetoscutula, Henningsiella, Johansonia, Leptophyma, Phillipsiella, Plochmopeltis, Pseudodiscus and Schizothyrium. Later, Müller and Farr (1971) included a new genus Cyanodiscus in Schizothyriaceae, however, the genus was recently placed in Saccardiaceae (Index Fungorum 2016).

Von Arx and Müller (1975) reassembled the classification of bitunicate ascomycetes and described Schizothyriaceae as being "saprobic fungi, mostly forming mycelia, with flattened, light or brownish, often inconspicuous hyphae, invading the cuticle, with superficial, scutate to dimidiate ascomata, lacking ostioles, bitunicate asci, parallel in a single layer, clavate, sphaerical to obovoid, paraphyses-like structures surrounded by a slimy mass and hyaline or brownish, septate ascospores" (von Arx \& Müller 1975, Hyde et al. 2013). Von Arx and Müller (1975) accepted 12 genera in Schizothyriaceae viz. Chaetoplaca, Henningsiella, Hexagonella, Leptophyma, Linopeltis, Mendogia, Metathyriella, Myriangiella, Neopeltella, Petrakina, Plochmopeltis and Schizothyrium. Allosoma, Chaetoscutula, Johansonia, Phillipsiella and Pseudodiscus, which were classified in Schizothyriaceae by Müller and von Arx (1962) have been transferred to the family Saccardiaceae. Clypeolum is currently placed in Dothideomycetes, genera incertae sedis, Polyclypeolum was treated as a synonym of Schizothyrium, while Phragmothyriella was synonymized under Myriangiella (von Arx \& Müller 1975, Index Fungorum 2016).

Barr (1979) accepted only five genera in Schizothyriaceae based on their superficial ascomata, with peridium cells not arranged in radiating rows, viz. Aulographum, Chaetoplaca, Linopeltis, Neopeltella and Schizothyrium. Eriksson (1981) described more clearly morphology of Schizothyriaceae based on Schizothyrium pomi which was treated as a synonym of the type species, S. acerinum. Eriksson (1981) mentioned that there was inconspicuous, superficial or subcuticular vegetative mycelium on the host and ascomata lacking radiating cells, lacked ostioles, and opened by several cracks. Additionally, Eriksson (1981) treated the family as a separate clade from Asterinales, the family had previously been placed in Asterinales by Barr (1979). Kirk et al. (2008) listed 16 genera in Schizothyriaceae, while Lumbsch and Huhndorf (2010) accepted only 15 genera and this was followed by Hyde et al. (2013). Ariyawansa et al. (2013) re-circumscribed the genera Dermatodothella, Dothideopsella, Grandigallia, Hysteropeltella and Gloeodiscus in the Dothideomycetes, genera incertae sedis and mentioned that Hysteropeltella was similar to the genera in Schizothyriaceae. Therefore, Ariyawansa et al. (2013) tentatively placed Hysteropeltella in Schizothyriaceae and this was followed by Wijayawardene et al. (2014).

The asexual morph of Schizothyriaceae has been reported as hyphomycetous and includes the genus Zygophiala (Batzer et al. 2005, 2008). Batzer et al. (2005) isolated the fungus from sooty blotch and flyspeck (SBFS) disease on apple and stated that Zygophiala was the asexual morph of Schizothyrium pomi based on its morphological characters and molecular support. Batzer et al. 
(2008) confused Schizothyrium as congeneric with Zygophiala. Therefore, Rossman et al. (2015) proposed to use Schizothyrium rather than Zygophiala, as it was the older name.

Recently, 16 genera were accommodated in Schizothyriaceae viz. Amazonotheca, Chaetoplaca, Henningsiella, Hexagonella, Hysteropeltella, Kerniomyces, Lecideopsella, Linopeltis, Mendogia, Metathyriella, Mycerema, Myriangiella, Neopeltella, Orthobellus, Plochmopeltis and Schizothyrium (= Zygophiala) (Wijayawardene et al. 2014, Rossman et al. 2015). Leptophyma was treated as a synonym of Microstroma in Microstromataceae, Microstromatales (Index Fungorum 2016).

The purpose of this study is to revisit the genera in Schizothyriaceae based on the morphological examination. Type or other specimens were loaned from herbaria worldwide to clarify the understanding of the family.

\section{Material and Methods}

Types or other specimens of genera in Schizothyriaceae were loaned from herbaria worldwide i.e. repositories of U.S. National Fungus Collections (BPI), the Botanic Garden Meise (BR), the Muséum National d'Histoire Naturelle (PC), the Swedish Museum of Natural History (S), the Universidade Federal de Pernambuco (URM), the Naturhistorisches Museum Wien (W) and the Yamaguchi University (YAM). Morphological characters were examined and re-described as in Hyde et al. (2013) and Phookamsak et al. (2014, 2015a, b).

Ascomata on herbarium material was observed under an Olympus SZH10 stereo microscope and cut as small pieces from the specimens. The ascomata were initially rehydrated in water or adding 3-5\% $\mathrm{KOH}$ for 5-10 minutes and the ascomata and peridium structures were studied from free hand sections. Squash mounts were obtained to determine the micromorphological characters such as asci, ascospores and hamathecium. Macro- and micromorphology were examined under the compound microscope (Phookamsak et al. 2014, 2015a, b).

Macro-morphological characters were captured using a Sony DSC-T110 digital camera under an Olympus SZH10 stereo microscope, while micro-morphological characters were captured using a Nikon ECLIPSE 80i compound microscope with DIC microscopy using a Cannon 550D digital camera or a Carl Zeiss microscope. Photographic plates were edited and combined using Adobe Photoshop version CS5 (Adobe Systems Inc., The United States). Morphological measurements were obtained using a Tarosoft $(\mathrm{R})$ Image Frame Work version 0.9 .7 and the software of Micro Imaging GmbH. AxioVs40 V 4.8.2.0 (2006-2010). Permanent slides were made by adding lactoglycerol and sealing with clear nail polish (Phookamsak et al. 2014, 2015a, b). Facesoffungi and Index Fungorum numbers are provided as described in Jayasiri et al. (2015) and Index Fungorum (2016).

\section{Results and discussion}

Many genera of Schizothyriaceae are doubtful and lack modern taxonomic study. In this study, the types and other specimens of the genera in the Schizothyriaceae were requested from herbaria worldwide and have been re-examined and are re-described. Morphological examination of the generic types and the representative specimens did not reveal superficial or subcuticular vegetative mycelia on the host, which differs from that reported by von Arx and Müller (1975) and Eriksson (1981). Only Linopeltis had vegetative hyphae surrounding the ascomata on the host. Some type specimens could not be located such as Kerniomyces, Metathyriella and Myriangiella and therefore morphological characters were obtained from the taxonomic literature, while Kerniomyces lacks a taxonomic description. Therefore, these three genera are treated in Schizothyriaceae, genera incertae sedis.

The type of Chaetoplaca was observed and examined. The sexual morph could not be clarified in this study, as there was only the asexual morph visible on the host. Therefore, the genus is tentatively placed in the Ascomycetes, genera incertae sedis. Henningsiella is similar to genera in the family Saccardiaceae in having discoid ascomata, composed of isodiametrical or radiating 
cells, while the peridium is thick at the base. Therefore, Henningsiella is transferred to Saccardiaceae. Hysteropeltella formed elongate, apothecial ascomata, similar to the genus Baggea in Patellariaceae (Yacharoen et al. 2015). Based on the ascomatal structures, we tentatively place the genus in Patellariaceae. Mendogia is transferred to the family Myriangiaceae, Myriangiales based on phylogenetic analyses (Dai et al. 2016).

Linopeltis is similar to genera in the family Aulographaceae in having elongate, thyriothecial ascomata with slit-like openings, but differs in having multi-septate ascospores. Therefore, we tentatively place this genus in Dothideomycetes, genera incertae sedis until the representative species is recollected and sequence data is obtained to clarify its placement. Neopeltella is excluded from Schizothyriaceae based on its thyriothecial ascomata.

Orthobellus differs from other genera in Schizothyriaceae in having narrowly anastomosing pseudoparaphyses and developed peridia at base of the setose ascomata, in dark mycelia colonies on the host. The morphological characters of the genus are unique and seem distinct from other epifoliar taxa. We therefore place the genus in Dothideomycetes, genera incertae sedis until the type is recollected and sequence data is obtained to clarify its placement.

Therefore, we accept five genera in Schizothyriaceae viz. Hexagonella, Lecideopsella, Mycerema, Plochmopeltis and Schizothyrium. These genera have a unique character in forming membranous, multi-loculate ascostromata, with each ascus forming in a locule, which is a "cell" in a network-like structure and in lacking ostioles. Descriptions and illustrations are provided in this manuscript.

\section{Taxonomy}

Schizothyriaceae Höhn. ex Trotter, Sacc., D. Sacc. \& Traverso [as 'Schizothyrieae'], in Saccardo, Syll. fung. (Abellini) 24(2): 1254 (1928)

FoF 01932

Epiphytic, pathogenic or saprobic, upper and/or lower surface of leaves of various plants, visible as dark brown or dark grey to black dots on the host surface. Sexual morph: Ascostromata scattered, solitary to gregarious, superficial, flattened, circular to ellipsoid, light brown or dark brown to black, transparent to opaque, scutate to dimidiate, or orbicular, glabrous, multi-loculate, with each ascus forming in a locule, which is a "cell" in a network-like structure, membranous, lacking ostioles, or opening by splitting of the upper wall. Peridium thin-walled, poorly-developed at the base, composed of light brown to dark brown, or black, of pseudoparenchymatous, or membranous cells, arranged in textura angularis to textura globulosa. Asci 4-8-spored, bitunicate, globose to subglobose, obovoid to clavate, sessile to subsessile, or short pedicellate, apically rounded, with an ocular chamber. Ascospores overlapping tri- to tetra- seriate, hyaline to subhyaline, oblong to ellipsoidal, or claviform, septate, constricted at the septum, thin- to thickwalled, smooth to rough, with small guttules. Asexual morph: Undetermined.

Generic type - Schizothyrium Desm.

Notes - Schizothyriaceae is a poorly understood family which comprises various ambiguous genera, mostly confused with the genera in Micropeltidaceae (Müller \& von Arx 1962, von Arx \& Müller 1975). The natural placement of the family has been discussed and treated in various orders (von Arx \& Müller 1975, Barr 1979, 1987, Batzer et al. 2008, Crous et al. 2009, Hyde et al. 2013, Wijayawardene et al. 2014). Saccardo (1928) accommodated the family in Phacidiales when the family was introduced. Whereas, von Arx and Müller (1975) treated the family as a member of the then broadly treated Dothideales. Barr (1979) assigned Schizothyriaceae to Asterinales, while Eriksson (1981) disagreed with Barr (1979) and treated the family as a separate clade. Later, Barr (1987) removed Schizothyriaceae from Asterinales and reassigned the family in the order Myriangiales.

Phylogenetic analyses of Schizothyriaceae have been carried out by Batzer et al. (2005, 2008) and Crous et al. (2007, 2009) based on Schizothyrium pomi and its asexual morph (Zygophiala). Based on their analyses, Schizothyriaceae was accommodated in the order 
Capnodiales and has shown to be allied to Mycosphaerellaceae (Batzer et al. 2005, 2008, Crous et al. 2007, 2009, Yang et al. 2010). Hyde et al. (2013) and Wijayawardene et al. (2014) however, treated the family in Dothideomycetes, families incertae sedis.

The geographic distribution of Schizothyriaceae is widespread, having been reported from both temperate and tropical regions (Barr 1987, Farr \& Rossman 2015). Members of the family are described from Brazil, China, Hong Kong, India, Japan, Philippines, Puerto Rico and USA (Farr \& Rossman 2015). Species in Schizothyriaceae are mostly epiphytic on dicotyledons (e.g. Acer, Quercus and Prunus) and they have also been found on monocotyledons such as bamboo (Farr \& Rossman 2015).

In this study, we examined the generic type, Schizothyrium acerinum from Desmazières's collections (deposited in BR and PC) and designated the specimen from BR as a lectotype. Based on morphological examination of Schizothyrium, we conclude that Schizothyriaceae may belong in the order Myriangiales as suggested by Barr (1987). The arrangement of the asci in the ascostromata of Schizothyrium acerinum and other genera of Schizothyriaceae can be interpreted in two ways. Either, it can be considered as multi-loculate, with each ascus forming within a "cell", which is a component of a thin network-like structure and that fills the ascostromata, and each "cell" can be considered as an individual locule. This is somewhat similar to species of Myrangiales. Alternatively, the ascostromata can. We use the first interpretation here and therefore do not describe the hamathecium. However, genera in Schizothyriaceae mostly lack molecular data and phylogenetic investigation. There are 34 sequences for Schizothyrium pomi and 217 sequences of Zygophiala spp., the asexual morph of Schizothyrium, available in GenBank. Whereas, other genera in Schizothyriaceae lack molecular data. Therefore, representative species need to recollected and epitypified (sensu Ariyawansa et al. 2014) as molecular data are required to resolve the natural placement of genera.

\section{Key to genera of Schizothyriaceae}

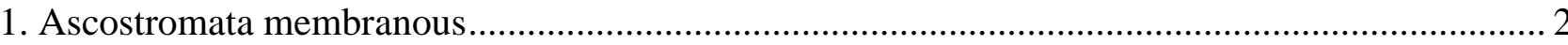

1. Ascostromata lacking covered layers, forming brown hyphae, branching at the apex, which are associated among the asci

Plochmopeltis

2. Ascospores 1-septate

2. Ascospores 2-septate, asci forming in hexagonal cell meshes Hexagonella

3. Ascostromata composed of pseudoparenchymatous cells

3. Ascostromata composed of delicate, light brown, to grey-brown membranous cells, ascospores smooth-walled.

Lecideopsella

4. Ascostromata composed of hyaline to subhyaline, pseudoparenchymatous cells, ascospores smooth-walled, associated only on Vochysiacea sp.

Mycerema

4. Ascostromata composed of dark brown to black pseudoparenchymatous cells, ascospores roughwalled, with small guttules, associated on a wide range of hosts.

Schizothyrium

Schizothyrium Desm., Annls Sci. Nat., Bot., sér. 3 11: 360 (1849)

FoF 01933

Epiphytic, or saprobic on leaves or branches of various flowering plants. Sexual morph: Ascostromata scattered, solitary to gregarious, superficial or subcuticular, flattened, dark, circular to ellipsoid, hemisphaerical, glabrous, multi-loculate, with each ascus forming in a locule, which is a "cell" in a network-like structure, opening by splitting of the upper wall. Peridium thin-walled, poorly-developed at the base, composed of dark brown to black pseudoparenchymatous cells, arranged in a textura angularis to textura globulosa. Asci 8-spored, bitunicate, subglobose to ovoid, sessile, apically rounded with indistinct ocular chamber, thick-walled at the apex, each ascus resting in a space between the mycelial networks. Ascospores overlapping bi- to tri-seriate, hyaline, ellipsoidal or oblong, 1-septate, slightly constricted at the septum, wider in upper cell, thick and rough-walled with small guttules. Asexual morph: Undetermined, but see notes. 
Notes - Schizothyrium was introduced by Desmazières (1849) and is typified by Schizothyrium acerinum Desm. The generic type was originally described as "ascomata perithecial, sessile, solitary, subfleshy, rounded to ovoid, plane to low convex, minute, punctiform, longitudinal rim opening, with ovoid ascospores" and was collected from Acer negundo L. (Desmazières 1849). Von Arx and Müller (1975) synonymized many genera under Schizothyrium viz. Microsticta Desm., Agyronella Höhnel, Microthyriella Höhnel, Epipeltis Theiss. Polyclypeolum Theiss., Eremotheca Theiss. \& Syd., Endocycla Syd., Gyrothyrium v. Arx, Myiocopraloa Ciferri, Didymopeltis Batista \& Lima, Schizopeltis Batista \& Lima, Schizothyrina Batista \& Lima, Paraphysotheca Batista [as P. brosimi $=$ S. rufulum (Berk. \& Curt.) v. Arx], Schizonthopeltis Batista \& Maia, Mycerema Batista et al. and Vanudenia Batista \& Maia [as V. nectandrae $=S$. longisporum (Pat.) v. Arx] and these should be restudied. Eriksson (1981) re-circumscribed the genus based on Schizothyrium pomi (Mont. \& Fr.) Arx and mentioned that Schizothyrium formed inconspicuous vegetative mycelium, with ascomata opening by several cracks. Eriksson (1981) described more clearly the morphological details of Schizothyrium, however, he could not find the longitudinal opening which was mentioned in Desmazières (1849). Hyde et al. (2013) examined a representative specimens which were collected from Desmazières (1863) and mentioned that Schizothyrium did not form superficial or subcuticular vegetative mycelium and ascomata have pore-like openings based on horizontal sections.

Schizothyrium occurs on leaves, stems, or other parts of various vascular plants such as Acer, Artocarpus, Bambusa, Crataegus, Gaultheria, Ilex, Malus, Phyllostachys, Pinus and Quercus and has been found in several countries in both temperate and tropical regions (Eriksson 1981, Farr \& Rossman 2015). There are 59 epithets for Schizothyrium in Index Fungorum (2016). However, most species lack modern taxonomic descriptions and molecular data to confirm the natural placements. Molecular data is only available in GenBank for S. pomi and its asexual morph. Therefore, the type species needs recollecting to obtain molecular data for determining the placement of Schizothyrium sensu stricto.

The asexual morph of Schizothyrium has been reported as hyphomycetous in the genus Zygophiala E.W. Mason for S. pomi (Batzer et al. 2005, 2008, Kirk et al. 2008, Ma et al. 2010, Hyde et al. 2013, Wijayawardene et al. 2012, 2014). The species has been reported from a wide range of hosts and a wide geographic distribution, mostly causing fly speck on apple and pear fruits (Batzer et al. 2005, 2008). The connection between Schizothyrium pomi and Zygophiala jamaicensis was initially reported by Durbin et al (1953) when they inoculated apple fruit with ascospores, and obtained both sexual and asexual morphs. Batzer et al. (2005) had also opinioned that the type species of Zygophiala, Z. jamaicensis was the asexual morph of S. pomi. Although, Batzer et al. (2008) later considered Z. jamaicensis as distinct from S. pomi, these genera have been shown to be congeneric in phylogenetic studies (Ma et al. 2010, Gao et al. 2014). Therefore, Rossman et al. (2015) choose the name Schizothyrium over Zygophiala as it was the older name. Additionally, Rossman et al. (2015) combined nine species in Schizothyrium which were previously named Zygophiala. Schizothyrium pomi is similar to $S$. acerinum in some aspects, but in other is unrelated and this will be the subject of a later paper.

Type species - Schizothyrium acerinum Desm.

Schizothyrium acerinum Desm., Annls Sci. Nat., Bot., sér. 3 11: 360 (1849) FoF 01934

Fig. 1

Epiphytic, or saprobic on branches of Acer. Sexual morph: Ascostromata 30-70 $\mu \mathrm{m}$ high, 160-330 $\mu \mathrm{m}$ diam., scattered, solitary to gregarious, superficial, flattened, dark brown to black, circular to ellipsoid, hemisphaerical, glabrous, multi-loculate, with each ascus forming in a locule, which is a "cell" in a network-like structure, opening by slit-like cracking of the upper wall. Peridium 7-15 $\mu \mathrm{m}$ wide, thin-walled, poorly-developed at the base, composed of 1-3 layers of dark brown to black pseudoparenchymatous cells, arranged in a textura angularis to textura globulosa 


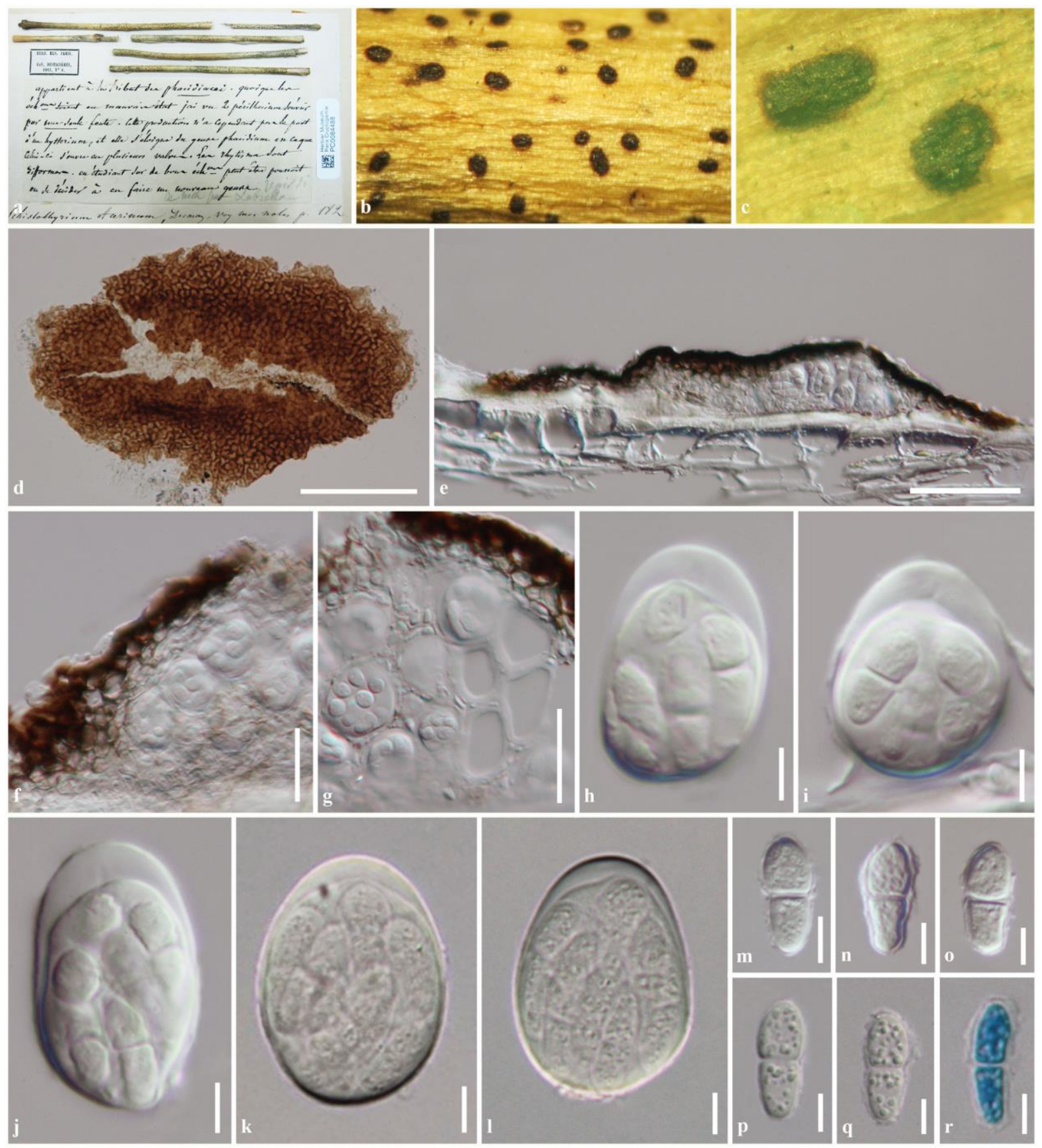

Fig. 1 - Schizothyrium acerinum (PC0084488, author's specimen and BR5020103861716, lectotype). a. Label and specimens from PC. b, c. Appearance of ascostromata on the host surface (b: from PC, c: from BR). d. Squash of ascostroma visualized under the compound microscope (from BR). e. Section through ascostroma (BR). f. Section through peridium (BR). Network-like structure in horizontal section (BR). $h-1$. Asci stained in lactoglycerol $(h-j=$ from $B R, k, l=$ from PC). m-o. Ascospores stained in lacto glycerol (BR). p, q. Ascospores (PC). r. Ascospore stained with cotton blue (PC). Scale bars: $d=100 \mu \mathrm{m}, \mathrm{e}=50 \mu \mathrm{m}, \mathrm{f}, \mathrm{g}=20 \mu \mathrm{m}, \mathrm{h}-1, \mathrm{~m}-\mathrm{v}=5 \mu \mathrm{m}$.

Asci $20-27 \times 13-16.5 \mu \mathrm{m}(\bar{x}=23.9 \times 15 \mu \mathrm{m}, \mathrm{n}=15), 8$-spored, bitunicate, subglobose to ovoid, sessile, apically rounded with indistinct ocular chamber, thick-walled at the apex, each ascus arranged in angular mycelial network. Ascospores $(12.5-) 13-15 \times 5-6 \mu \mathrm{m}(\bar{x}=14.4 \times 5.9 \mu \mathrm{m}, \mathrm{n}=$ 20), overlapping irregularly seriate, hyaline, ellipsoidal or oblong, 1-septate, slightly constricted at the septum, wider in upper cell, thick and rough-walled, with small guttules. Asexual morph: Undetermined. 
Material examined - FRANCE, Paris, dead branch of Acer negundo L. (Sapindaceae), 1863, Desmazières, PC0084488; ibid. on dry twigs of Acer negundo L, Desmazières, BR5020103861716, lectotype is designated here).

Notes - Schizothyrium acerinum is a poorly understood species, and subsequently authors often choose $S$. pomi to represent the morphological characters of the genus Schizothyrium. Schizothyrium pomi was treated as a synonym of S. acerinum by Eriksson (1981). The former is well-known to cause sooty blotch and flyspeck (SBFS) disease on apples and pears (von Arx 1959a, Eriksson 1981, Batzer et al. 2005, 2008). Schizothyrium acerinum is similar to S. pomi in having ovoid to subglobose, or ellipsoid to clavate asci with hyaline, fusoid to ellipsoidal guttulate, thick-walled, 1-septate ascospores. However, S. pomi differs from S. acerinum in having larger ascomata and asci and lacking ostioles, and having a peridium composed of an irregular meandering arrangement of compact hyphae and being associated with apples and pears. Schizothyrium pomi forms pseudoparaphysoid-like filaments among the asci, while in S. acerinum there is a network-like structure, and each ascus is arranged in an angular mycelial "cell". The latter species has only been reported from Acer. Fresh collections of S. acerinum are needed to establish the placement of the genus in the Dothideomycetes and whether S. pomi is related to S. acerinum.

Hexagonella F. Stevens \& Guba ex F. Stevens, Bulletin of the Bernice P. Bishop Museum, Honolulu, Hawaii 19: 89 (1925)

FoF 01935

Fig. 2

Epiphytic on upper surface of leaves of Pelea rotundifolia. Sexual morph: Mycelium superficial, branched, forming a flattened, net-like thallus. Ascostromata scattered, solitary, superficial, with little cuticular connection, dark brown, rounded, plane, cushion-like, glabrous, multi-loculate, with each ascus forming in a locule, which is a "cell" in a network-like structure, comprising a disk, with dense, woven mycelium, the central disk surrounded by irregular periphery of sparsely interwoven, loosely, branched, spreading hyphae, lacking ostioles. Peridium composed of a thick, hexagonal, mesh-like structure, with standing hyphae. Asci 8-spored, solitary, scattered in hexagonal cell-meshes, not covered by perithecia, each ascus resting in a space between the sterile cells. Ascospores overlapping, brown, ellipsoidal to oblong, 2-septate, constricted at the septum, broadest at the lowest cell, thick and smooth-walled. Asexual morph: Undetermined (description from Stevens 1925).

Type species - Hexagonella peleae F. Stevens \& Guba ex F. Stevens

Notes - Hexagonella was introduced by Stevens (1925) and is typified by Hexagonella peleae F. Stevens \& Guba ex F. Stevens. The genus was introduced to accommodate a single species which was collected on leaves of Pelea rotundifolia from Hawaii. Stevens (1925) mentioned that the genus was similar to various genera in the families Ascocorticiaceae, Hemisphaeriaceae, Myriangiaceae and Saccardiaceae. However, Hexagonella differs from Ascocorticiaceae in having asci arranged in hexagonal cells, with each ascus separated by sterile hyphae (Stevens 1925). The genus differs from Myriangiaceae and Saccardiaceae in forming rounded, plane, cushion-like ascostromata and asci arranged in a single-layered thallus (Stevens 1925). While, Myriangiaceae often formed sphaerical, pulvinate, discoid, scutate ascostromata and Saccardiaceae forms discoid ascomata, composed of isodiametrical or irregular cells (von Arx \& Müller 1975). Based on the naked and solitary asci with flat, thin, soft ascomata, Hexagonella was placed in the family Gymnopeltineae by Stevens (1925). Von Arx and Müller (1975) treated the genus in Schizothyriaceae and this was subsequently followed (Kirk et al. 2008, Lumbsch \& Huhndorf 2010, Hyde et al. 2013, Wijayawardene et al. 2014).

Hexagonella is a poorly known genus. The type specimen is located in ILLS and BPI (only micro-slide of ascomata available in BPI). We examined the micro-slide of ascomata from BPI, although the ascomata on the micro-slide differ from the original description and iconotype. Therefore, the representative species need to be recollected to clarifying the natural placement and a modern taxonomic description provided. Nevertheless, we tentatively place the genus in Schizothyriaceae as it has typical characters. 
Lecideopsella Höhn., Sber. Akad. Wiss. Wien, Math.-naturw. Kl., Abt. 1 118: 1229 [73 repr.] (1909)

\section{FoF 01936}

Epiphytic on upper and lower surfaces of leaves on various flowering plants. Sexual morph: Ascostromata scattered, gregarious, superficial, easily dispersed, visible as flattened, dark grey spots on the host surface, plane-scutate, uni-loculate, which is a "cell" in a network-like structure, glabrous, membranous, lacking ostioles. Peridium thin-walled, delicate, thinner towards the apex, poorly-developed at the base, composed of light brown, membranous cells. Asci 8-spored, bitunicate, globose to obovoid, with slightly short-curved pedicel or sessile, apically rounded, thick-walled at the apex. Ascospores overlapping, lying parallel, irregularly-seriate, hyaline to pale yellowish, oblong, 1-septate, slightly constricted at the septum, smooth-walled. Asexual morph: Undetermined (description from Höhnel 1909b).

Type species - Lecideopsella gelatinosa Höhn.

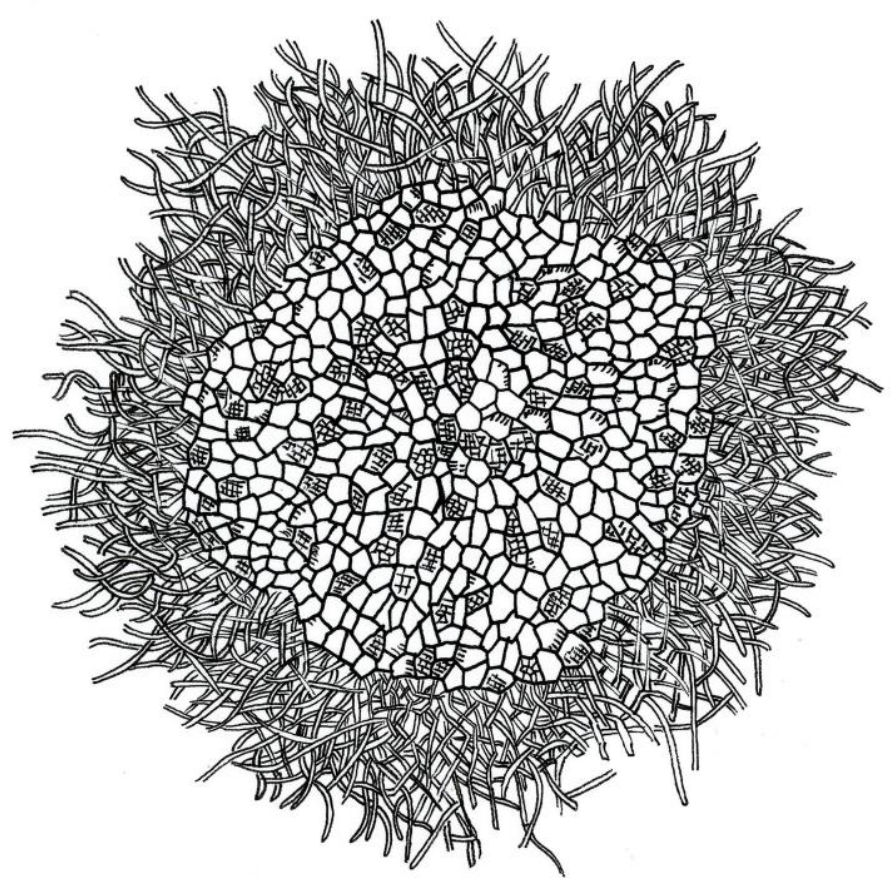

a. Appearance of ascomata on the host surface.

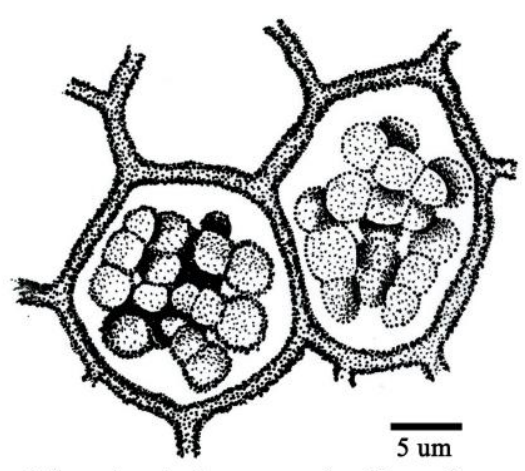

b. Asci forming in hexagonal cell meshes

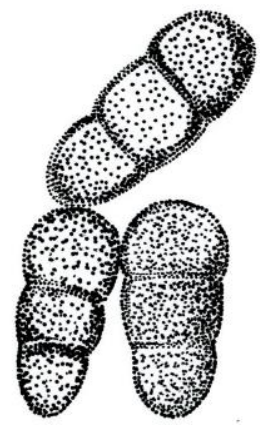

c. Ascospores

$\overline{5 \text { um }}$

Fig. 2 - Hexagonella peleae (redrawn from Stevens F.L. 1925, iconotype).

Notes - Lecideopsella was introduced by Höhnel (1909b) to accommodate an epifoliar fungus on Paratropia sp. in Indonesia, which was typified by L. gelatinosa Höhn. Höhnel (1909b) mentioned that the genus was related to Henningsiella Rehm, Lecideopsis (Almq.) Rehm., Leptophyma Sacc. and Phillipsiella Cooke. However, Lecideopsella differ from these genera due to its ascostromata and in having network-like structure while Henningsiella lacks pseudoparaphyses. Lecideopsis formed apothecial ascomata, erumpent through host epidermis, which turns red or blue when stained in iodine, while Lecideopsella forms plane-scutate ascomata, typically superficial on the host and does not turn blue when stained in iodine, (Rehm 1895, Höhnel 1909b). Leptophyma differs from Lecideopsella in having loose pseudoparaphyses, forming a colorless epithecium, and is articulariella-like (Höhnel 1909b), whereas, Phillipsiella has pseudoparaphyses, with short, black, branches and a loose filamentous hypothecia (Höhnel 1909b). 
Lecideopsella is a poorly known genus which accommodates 12 species in Index Fungorum (2016) and lacks molecular data. The genus has been collected from various flowering plants, mostly in tropical regions, such as India, Indonesia and Uganda (Farr \& Rossman 2015). Hansford (1944, 1945, 1946, 1947) introduced L. gelatinosa, using the same name with the type species (on Jasminum dichotomum Vahl), L. brideliae (on Bridelia micrantha (Hochst.) Baill.), L. landolphiae (on Landolphia florida Benth.) and L. ugandensis (on Artabotrys nitidus Engl.) to the genus Lecideopsella. Nevertheless, Müller and von Arx (1962) transferred L. brideliae and L. ugandensis to the genus Leptophyma. Pande (2008) circumscribed the ascomycetes of Peninsular in India and accommodated eight species in Lecideopsella viz. L. atra A. Pande, L. atra var. atra A. Pande, $L$. atra var. eugeniae A.B. Pawarn \& M.S. Patil ex A. Pande, L. aurantiaca (Ellis \& G. Martin) A. Pande, L. bakeri (Syd. \& P. Syd.) A. Pande, L. gelatinosa var. longispora (A.B. Pawar \& M.S. Patil) A. Pande, L. hyalina A. Pande and L. trinidadensis (F. Stevens) A. Pande.

Lecideopsella was treated as a synonym of Leptophyma and accommodated in Schizothyriaceae by von Arx and Müller (1975) and this was followed by Hawksworth et al. (1983) and Eriksson and Hawksworth (1985). Nevertheless, Eriksson and Hawksworth (1987) reinstated the genus and treated it in Schizothyriaceae. Subsequently, Lecideopsella was accommodated in Schizothyriaceae by various mycologists following Eriksson and Hawksworth's agreement (1985) (Eriksson \& Hawksworth 1987, Kirk et al. 2001, 2008, Lumbsch \& Huhndorf 2010, Hyde et al. 2013, Wijayawardene et al. 2014).

Lecideopsella gelatinosa Höhn., Sber. Akad. Wiss. Wien, Math.-naturw. Kl., Abt. 1 118: 1230 [74 repr.] (1909)

Fig. 3 FoF 01937

Epiphytic on lower surface of leaves of Paratropia sp. Sexual morph: Ascostromata 400 $1000 \mu \mathrm{m}$ diam. superficial, scattered, roundish, thinner towards the edge, delicate membranous, hyphae with membrane merging, gelatinous, brown-grey. Asci 32-35 × $28 \mu \mathrm{m}, 8$-spored, bitunicate, globose-ovoid, short pedicellate, thick-walled at the apex, with each ascus forming in a locule, which is a "cell" in a network-like structure. Ascospores $16 \times 7 \mu \mathrm{m}$, pale yellowish, ovateoblong, rounded at both ends, 1-septate, upper cell shorter and wider than lower cell, smoothwalled (description from von Höhnel 1909b)

Notes - Von Höhnel (1909b) compared the species with Agyronella lagunculariae (G. Winter) Höhn and considered that these two species are different in A. lagunculariae having a rather thick, dark, large cell hypothecium [a thin upper layer of the apothecial tissue on which the asci rest (Ulloa \& Hanlin 2000)], peculiar paraphyses and multi-septate ascospores.

The type specimen was located in the Harvard University Herbaria (FH, 00274523). However, the specimen is in poor condition and we could not observe the ascomata on the host. Therefore, the genus needs to be recollected and sequence data obtained to clarify its placement.

Lecideopsella paragelatinosa Phookamsak \& KD Hyde, nom. nov.

Fig. 4

IF 551990

FoF 01938

Replaced synonym - Lecideopsella gelatinosa Hansf., Proc. Linn. Soc. London 157: 38 (1945) [1944-45]

Etymology - Para- (Gr.: beside, next to, resemble, towards), the epithet "paragelatinosa" refers to the resembling the species Lecideopsella gelatinosa.

Annotation - Lecideopsella paragelatinosa is introduced to replace Lecideopsella gelatinosa Hansf. which is an illegitimate name.

Epiphytic on lower surface of leaves of Jasminum dichotomum Vahl. Sexual morph: Ascostromata 18-40 $\mu \mathrm{m}$ high, 400-630 $\mu \mathrm{m}$ diam., scattered, gregarious, superficial, easily to remove, flattened, as dark grey spots on the host surface, plane-scutate, glabrous, multi-loculate, with each ascus forming in a locule, which is a "cell" in a network-like structure, membranous, lacking ostioles. Peridium 3-8.5 $\mu$ m wide, thin-walled, poorly-developed at the base, composed of 

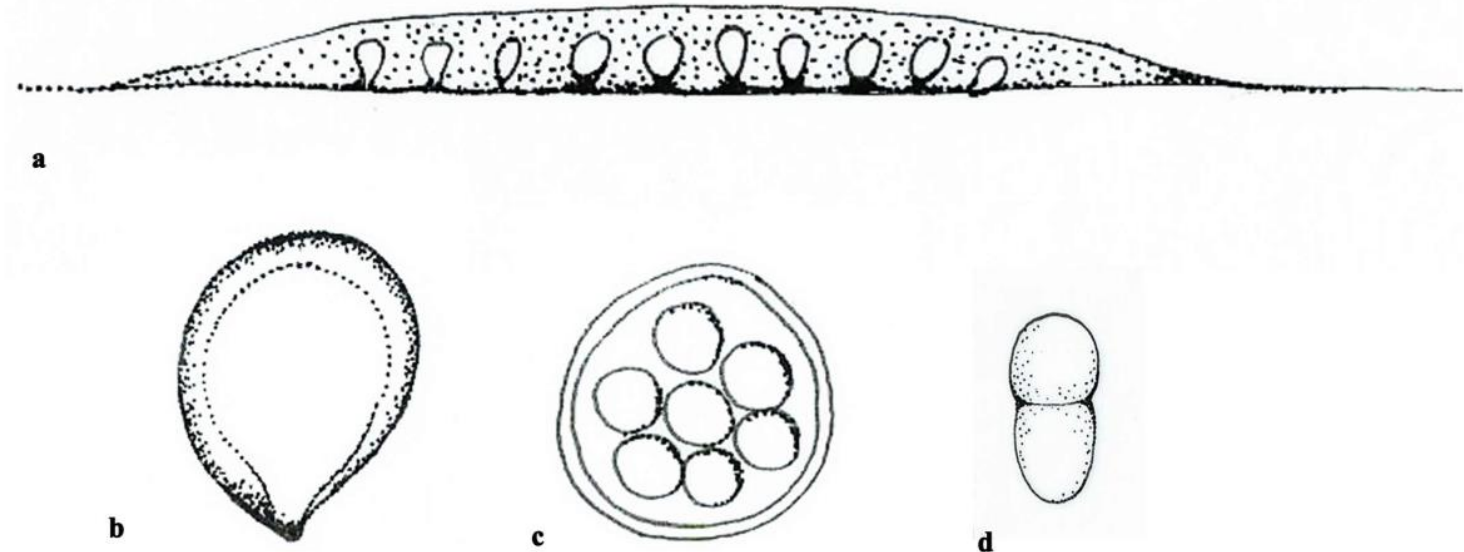

d

Fig. 3 - Lecideopsella gelatinosa (redrawn from Höhnel's herbarium package in FH, iconotype). a. Appearance of ascostroma on the host surface. b. Ascus. c Arrangement of ascospores in asci. d. Ascospore.

light brown, membranous cells Asci (19.5-)20-30(-33.5) $\times(12.5-) 13-15(-20) \mu \mathrm{m}(\bar{x}=27 \times 14.8$ $\mu \mathrm{m}, \mathrm{n}=20$ ), 8-spored, bitunicate, globose to obovoid, with slightly short, curved pedicel or sessile, apically rounded, thick-walled at the apex. Ascospores $(9-) 10-12(-15) \times 3-4.5 \mu \mathrm{m}(\bar{x}=11.3 \times 3.4$ $\mu \mathrm{m}, \mathrm{n}=30$ ), overlapping tri- to tetra-seriate, hyaline, oblong-clavate, 1-septate, constricted at the septum, smooth-walled, with long, germ tubes (15-45 $\mu \mathrm{m}$ long) at both ends. Asexual morph: Undetermined.

Material examined - UGANDA, on living leaves of Jasminum dichotomum Vahl (Oleaceae), November 1943, C. G. Hansford, BPI 667226 (type of Lecideopsella gelatinosa Hansf.)

Notes - Hansford (1945) introduced the epifoliar fungus on Jasminum dichotomum from Uganda, namely Lecideopsella gelatinosa Hansf., which had the same name as the type species and thus a homonym. However, the species differs from the type species in having smaller ascomata, asci and ascospores and has hyaline ascospores, while the type species has pale yellowish ascospores. Therefore, we rename the species as L. paragelatinosa (Hansf.) Phookamsak \& KD Hyde, the type material has germinated.

Mycerema Batista et al., in Batista et al., Publicações Inst. Micol. Recife 392: 5 (1963)

Fig. 5 FoF 01939

Epiphytic on upper surface of leaves of Vochysiacea sp. Sexual morph: Mycelium free, superficial, brown, glabrous, reticular, septate, non-hyphopodiate. Ascostromata scattered, solitary, superficial, brown, plane, orbicular, dimidiate, glabrous, membranous, lacking ostioles, with irregular dehiscence. Peridium thin-walled, poorly-developed at the base, composed of hyaline to subhyaline, reticular, pseudoparenchymatous cells. Asci 8-spored, bitunicate, oblong to globose, sessile, apically rounded. Ascospores overlapping irregular seriate, hyaline, claviform, 1-septate, slightly constricted at the septum, smooth-walled. Asexual morph: Undetermined (description from Batista et al. 1963)

Type species - Mycerema vochysiacearum Batista et al. 

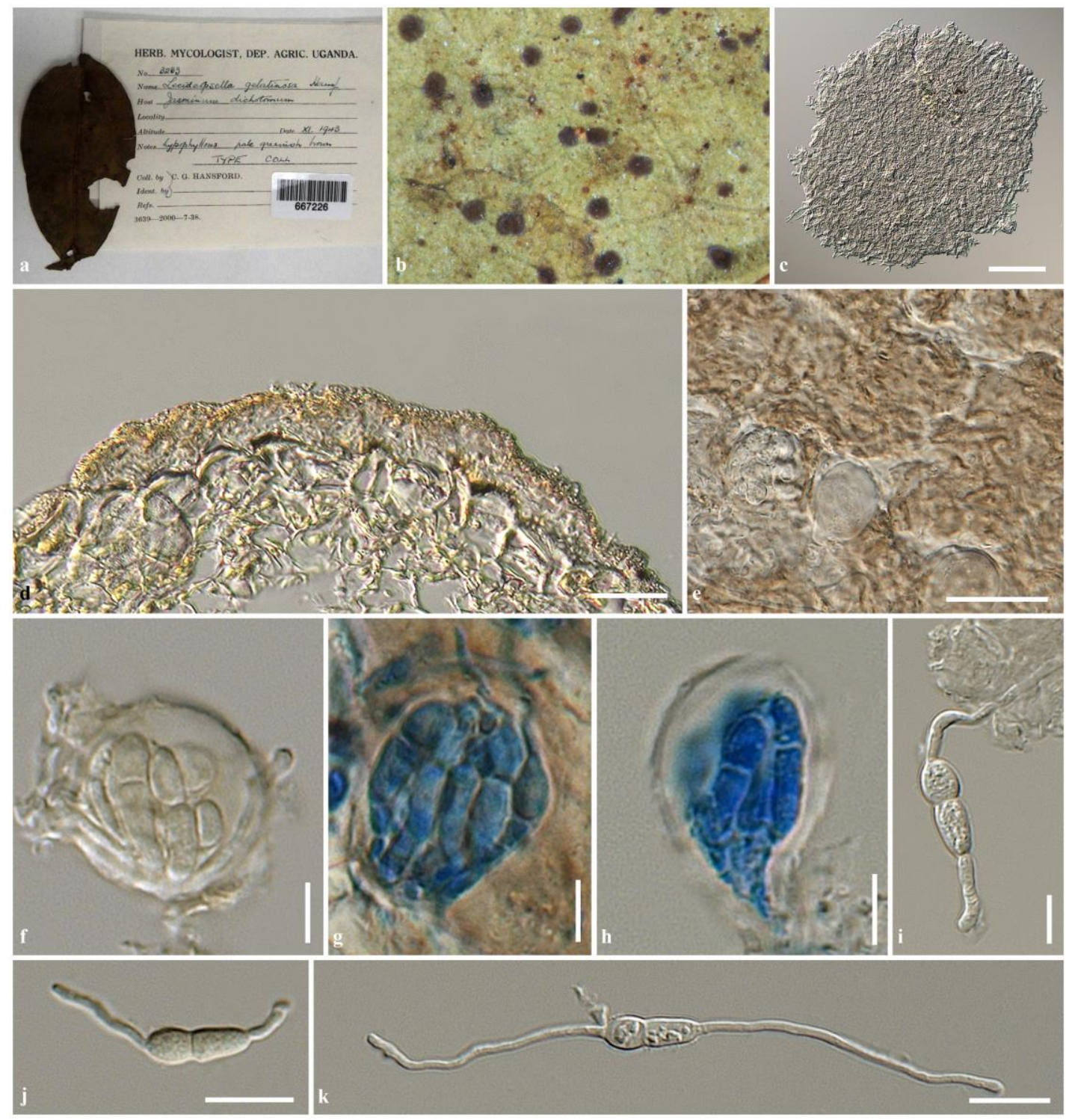

Fig. 4 - Lecideopsella paragelatinosa (BPI 667226, holotype of Lecideopsella gelatinosa Hansf.). a. Herbarium specimen from BPI. b. Appearance of ascomata on the host surface. c. Squash mount of ascoma visible under the compound microscope. d. Section through ascostroma. e. Peridium structure visualized from above. f. Ascus. g, h. Asci stained in cotton blue. i-k. Ascospores which have germinated. Scale bars: $\mathrm{c}=100 \mu \mathrm{m}, \mathrm{d}, \mathrm{e}=20 \mu \mathrm{m}, \mathrm{j}, \mathrm{k}=10 \mu \mathrm{m}, \mathrm{f}-\mathrm{i}=5 \mu \mathrm{m}$.

Notes - Mycerema was introduced by Batista et al. (1963) to accommodate a single species M. vochysiacearum. The type species was found on leaves of Vochysiacea sp. in Brazil. Batista et al. (1963) mentioned that Mycerema vochysiacearum was associated with Vizella bingervilliana C. Moreau \& M. Moreau and Plenotrichaius hiloensis Bat. \& J.L. Bezerra. Hyde et al. (2013) examined the type of $M$. vochysiacearum and transferred it to the genus Vizella (Vizellaceae).

We therefore examined the same specimens as Hyde et al. (2013) (Brazil, Ponta Negra, Manaus, Amazonas, on Vochysiacea sp., 18 September 1961, J.M. Carvalho (Leg.), A.C. Batista and W. Cavalcanti (Det.), URM 25844), and found that the type specimen is in poor condition and lacked ascomata of Mycerema vochysiacearum. Vizella bingervilliana was found and examined and is same taxon that Hyde et al. (2013) had examined and treated as Vizella vochysiacearum. Additionally, we observed the protologue and iconotype of Mycerema vochysiacearum and found that the protologue did not match with the taxon that we found on the host. Therefore, we consider that the taxon on the host is Vizella bingervilliana following Batista et al. (1963). Hence, we reinstate $M$. vochysiacearum as the type of Mycerema. 

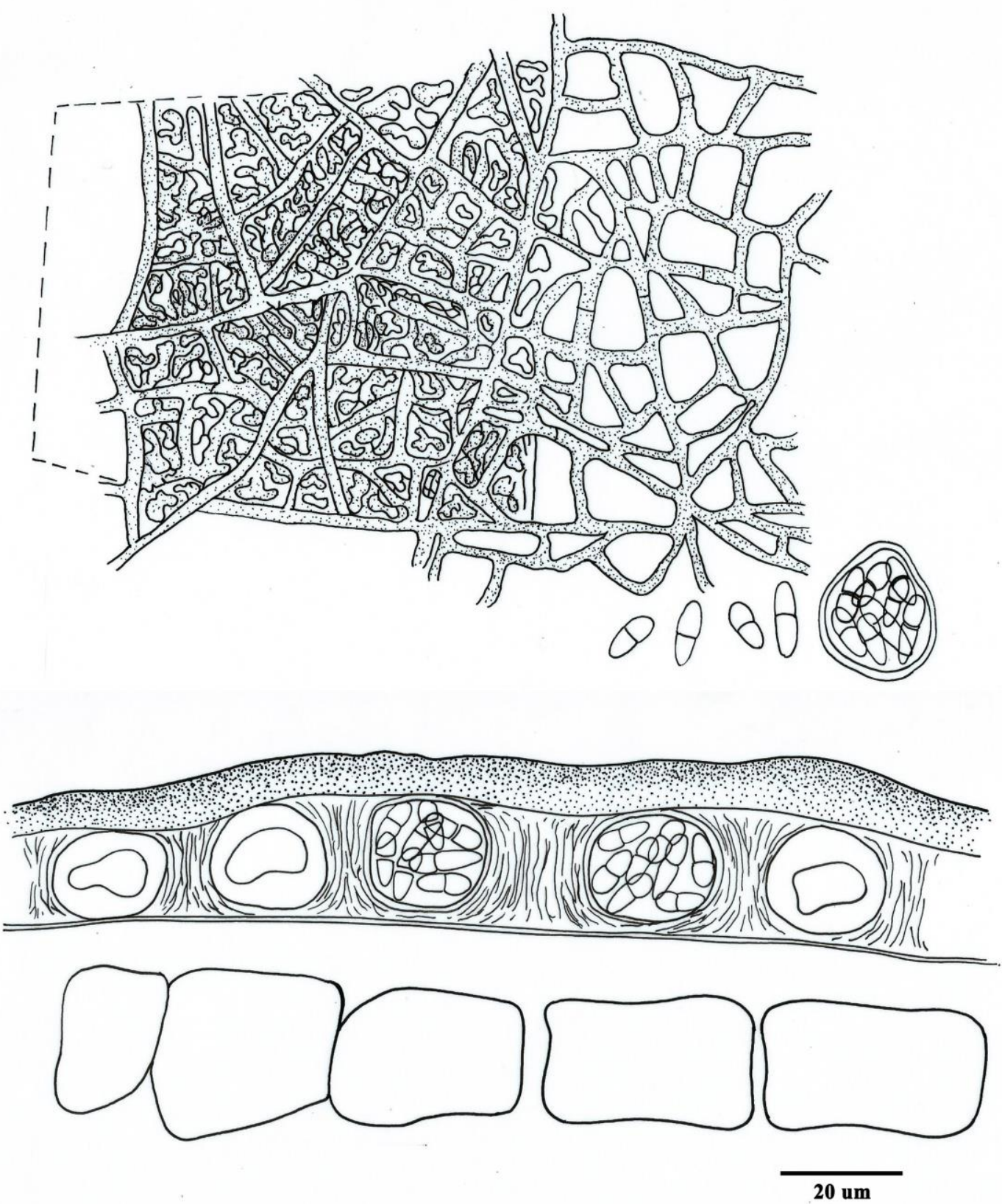

Fig. 5 - Mycerema vochysiacearum (redrawn from Batista et al. 1963, iconotype).

Mycerema is a poorly known genus which lacks modern taxonomic description and molecular data is needed to resolve its natural placement. There are only two epithets available in Index Fungorum (2016). Mycerema vochysiacearum had been transferred to the genus Vizella by Hyde et al. (2013). However, we reinstate this species as Mycerema in this study. Mycerema chandleri (Hansf.) M.L. Farr has currently been treated as Bonaria chandleri (Hansf.) Bat. in the family Micropeltidaceae (Index Fungorum 2016). Hyde et al (2011) and Wijayawardene et al. (2012) reported the asexual morph of Mycerema as the coelomycetous genus Plenotrichaius. However, Wijayawardene et al. (2014) treated the genus in Dothideomycetes, genera incertae sedis.

We tentative placed Mycerema in Schizothyriaceae based on its morphological characters. Recollection of the representative species, with sequence data is needed to clarify the taxonomic placement. 
Epiphytic on lower surface of leaves of Quercus spp. and some flowering plants. Sexual morph: Ascostromata scattered, solitarily, flattened, brown to dark brown, superficial, dimidiate to scutate, or crustaceous, multi-loculate, without walls, lacking peridia, covering by reddish brown hyphae, septate, roughly coarse, with brown to reddish brown mycelium clumps at the top, or membranous, composed of subhyaline to light brown, mycelial networks, with each ascus forming in a locule, which is a "cell" in a network-like structure. Asci 8-spored, bitunicate, fissitunicate, globose to subglobose, or clavate, short to long pedicellate, apically rounded with obtuse ocular chamber and thick apex. Ascospores overlapping irregular tri- to penta-seriate, hyaline, ellipsoidal to oblong or clavate, septate, slightly constricted at the septum, smooth-walled. Asexual morph: Undetermined.

Type species - Plochmopeltis intricata (Ellis \& G. Martin) Theiss.

Notes - Plochmopeltis was introduced by Theissen (1914) to accommodate the epiphytic taxon, forming hypophyllous, superficial ascomata on leaves of Quercus arenaria Borbás in Florida, USA. The genus was typified by Plochmopeltis intricata (Ellis \& G. Martin) Theiss., which was previously identified as Asterina intricata Ellis \& G. Martin.

Several epiphytic collections from Florida, with flattened, sessile, superficial ascomata on the host cuticle, were mostly classified as "Asterelia" by Saccardo (1891). However, Theissen (1912) re-classified these taxa and accommodated them in different genera such as Calothyrium Theiss., Microthyriella Höhn., Microthyrium Desm. and Stomiopeltis Theiss. (von Arx 1959b). The relevant species described on Quercus laurifolia Michx. were initially classified as Microthyriella by Theissen (1912) and Petrak (1929). Later, Theissen (1914) placed it in the genus Plochmopeltis. Theissen (1914) and Petrak (1929) mentioned that Plochmopeltis formed peridia with small plectenchymatous cells (von Arx 1959b). Von Arx (1959b) re-circumscribed the genus Plochmopeltis based on the type specimen of Asterina intricata and mentioned that Plochmopeltis did not form peridia, but had confluent mycelium with clumps at the apex, covering the asci. Additionally, von Arx (1959b) introduced a new species, Plochmopeltis ellisii Arx. Müller and von Arx (1962), included two other species, Plochmopeltis roupalae (Syd.) Arx (三 Microthyriella roupalae Syd.) and Plochmopeltis graminicola (Höhn.) Arx (三 Microphyma graminicola Höhn.). Gómez (1998) introduced a new species Plochmopeltis rodriguezii from leaves of Eugenia axillaris from Cuba.

Recently, five species are accommodated in the genus (Index Fungorum 2016), but they lack molecular data and phylogenetic investigation. Species of Plochmopeltis occur on various hosts and are distributed in tropical to subtropical regions, such as Brazil, Cuba, Ecuador, Florida (USA), and the West Indies (Arx 1959b, Müller \& von Arx 1962, Farr \& Rossman 2015).

Based on examination of the type, we agree with von Arx (1959b) that the genus Plochmopeltis forms superficial ascomata on the host, lacks a peridium, but forms confluent mycelium, with brown hyphae clumps at the apex covering the asci and indistinct network-like structure. Plochmopeltis differs from other genera in Schizothyriaceae in forming confluent mycelium with brown hyphae clumps at the apex covering the asci, and in lacking a peridium. Therefore, we place the genus in Schizothyriaceae until representative species are recollected and molecular data is obtained to clarify the natural placement.

Plochmopeltis intricata (Ellis \& G. Martin) Theiss., Brotéria, sér. bot. (1914) FoF 01941

$\equiv$ Asterina intricata Ellis \& G. Martin, Am. Nat. 18: 69 (1884)

Epiphytic on lower surface of leaves of Quercus arenaria Borbás. Sexual morph: Ascostromata 280-430 $\mu \mathrm{m}$ diam., scattered, solitary, dense, flattened, of brown to dark brown hyphae, superficial, dimidiate to scutate or crustaceous, multi-loculate, with each ascus forming in a locule, which is a "cell" in a network-like structure, forming confluent mycelium with brown hyphae clumps at the apex covering the asci, without a distinct wall, lacking ostioles. Mycelium 1-3 
$\mu \mathrm{m}$ wide, brown to reddish brown, septate, roughly coarse, branching, botryose elements, straight or curved. Asci 17.5-35 × 15-17 $\mu \mathrm{m}(\bar{x}=26.4 \times 16.5 \mu \mathrm{m}, \mathrm{n}=20)$, 8-spored, bitunicate, fissitunicate, globose to subglobose, or clavate, short to long pedicellate (2.5-10 $\mu \mathrm{m}$ long), apically rounded, with obtuse ocular chamber and thickened apex. Ascospores $12.5-15 \times 2.5 \mu \mathrm{m}(\bar{x}=13.3$ $\times 2.5 \mu \mathrm{m}, \mathrm{n}=20$ ), overlapping irregular tri- to penta-seriate, hyaline, ellipsoidal to oblong or clavate, 1-septate, slightly constricted at the septum, larger in the upper cell, smooth-walled. Asexual morph: Undetermined.

Material examined - USA, Florida - 29.99\%-81.68 , on leaves of Quercus arenaria (Fagaceae), 13 March 1883, Martin, no. 176 (W Krypto 1978-0015085, type of Asterina intricata).

Notes - When Theissen (1914) introduced a new genus Plochmopeltis, he designated $P$. intricata as the type species, which is based on Asterina intricata. Plochmopeltis intricata was collected on leaves of Quercus arenaria from Florida. The species is most similar to P. ellisii, but differs in having dark brown, dense mycelium, with more highly branched of mycelium clumps. Ascospores of $P$. ellisii are more rounded than $P$. intricata, while $P$. ellisii has a brighter and sparse, superficial mycelium.

Plochmopeltis roupalae (Syd.) Arx, in Müller \& von Arx, Beitr. Kryptfl. Schweiz 11(no. 2): 209 (1962)

FoF 01942

Fig. 7

इ Microthyriella roupalae Syd., Annls mycol. 25(1/2): 95 (1927)

Epiphytic on lower surface of leaves of Roupala veraguensis Klotszch. Sexual morph: Ascostromata 20-35 $\mu \mathrm{m}$ high, 130-250 $\mu \mathrm{m}$ diam., scattered, solitary, flattened, brown to dark brown, circular or ellipsoidal, superficial, crustaceous to quadrilateral, multi-loculate, with each ascus forming in a locule, which is a "cell" in a network-like structure, forming branching hyphae, terminated in dark brown, botryose elements, membranous, lacking ostioles. Mycelium 1-3 $\mu \mathrm{m}$ wide, hyaline, septate, smooth, with brown to dark brown, flower-like tufting apices. Pseudoepithecium 1-5.5 $\mu \mathrm{m}$ thick, botryose elements, with loose mycelia merging with thin membranous covering the fungal contents. Asci $(15-) 17-23(-25) \times 9-12(-13) \mu \mathrm{m}(\bar{x}=21.4 \times 11$ $\mu \mathrm{m}, \mathrm{n}=30$ ), 8 -spored, bitunicate, globose to subglobose, or clavate, short to long pedicellate (3-8 $\mu \mathrm{m}$ long $)$, apically rounded with plane and thick apex. Ascospores $6-7(-8) \times 2-3 \mu \mathrm{m}(\bar{x}=7.1 \times$ $2.9 \mu \mathrm{m}, \mathrm{n}=30$ ), overlapping, irregularly tri- to penta-seriate, hyaline, ellipsoidal to oblong or clavate, 1-septate, slightly constricted at the septum, smooth-walled. Asexual morph: Undetermined.

Material examined - COSTA RICA, Alajuela, Mondongo pr. San Ramon, on leaves of Roupala veraguensis (Proteaceae), 3 February 1925, H. Sydow, no. 229c (S-F61524, syntype of Microthyriella roupalae Syd.).

Notes - Plochmopeltis roupalae differs from $P$. intricata in having loose mycelia merging with membranous cells covering ascomata and less botryose elements than $P$. intricata. Plochmopeltis roupalae also has smaller ascomata, asci and ascospores, as compared to $P$. intricata.

\section{Schizothyriaceae, genera incertae sedis}

Kerniomyces Toro, J. Agric. Univ. Puerto Rico 22: 452 (1939)

Type species - Kerniomyces costi Toro, J. Agric. Univ. Puerto Rico 22: 453 (1939)

Notes - Kerniomyces costi was collected on Costus macrostachys (Costaceae) from Venezuela. Petrak (1950a) treated the genus in Myriangiales, while Eriksson and Hawksworth (1985) placed Kerniomyces in Schizothyriaceae and this was followed by subsequent authors (Eriksson \& Hawksworth 1987, Kirk et al. 2001, 2008, Lumbsch \& Huhndorf 2010, Hyde et al. 2013, Wijayawardene et al. 2014). We therefore, treat the genus in Schizothyriaceae, genera incertae sedis as the type material of the genus could not be located and lacks taxonomic description. 
Metathyriella Syd., Annls mycol. 25(1/2): 96 (1927)

Epiphytic on Crataegus crenulata (D. Don) M. Roem and Roupala veraguensis Klotszch. Sexual morph: Ascomata thyriothecial, scattered, scutate or hemisphaerical, with indistinct basal membrane, plane-convex, completely closed, irregularly lumpy at the maturity, transparent, yellowish-brown or olive-brown. Hamathecium composed of dense, filiform, branched, reticulate paraphyses. Asci 8-spored, bitunicate, broadly ellipsoid to ovoid, sessile. Ascospores overlapping parallel uni-seriate, hyaline, oblong-clavate, 2-septate, moderate. Asexual morph: Undetermined (description from Sydow 1927).

Type species - Metathyriella roupalae Syd.
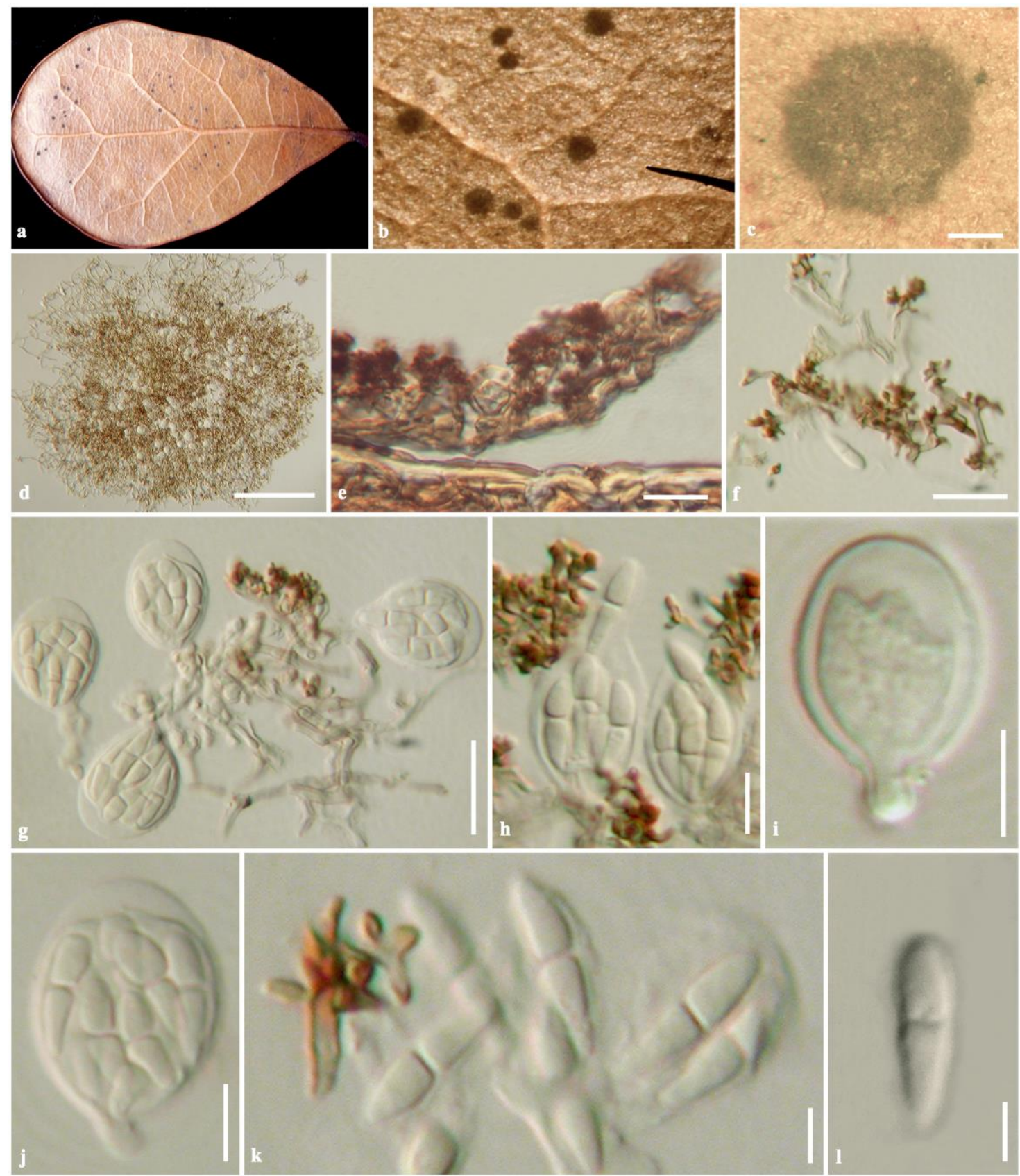

Fig. 6 - Plochmopeltis intricata (W Krypto 1978-0015085, type of Asterina intricata Ellis \& G. Martin). a. Herbarium specimen from W. b, c. Appearance of ascostromata on the host surface. d. Squash mount of ascostroma visualized under the compound microscope. e. Section through ascostroma. f. The confluent mycelium with botryose elements at the apex. g. Asci merging with a network-like structure. $\mathrm{h}-\mathrm{j}$. Asci. $\mathrm{k}, \mathrm{l}$. Ascospores. Scale bars: $\mathrm{c}, \mathrm{d}=100 \mu \mathrm{m}, \mathrm{e}, \mathrm{g}=20 \mu \mathrm{m}, \mathrm{f}, \mathrm{h}-\mathrm{j}=$ $10 \mu \mathrm{m}, \mathrm{k}, 1=5 \mu \mathrm{m}$. 


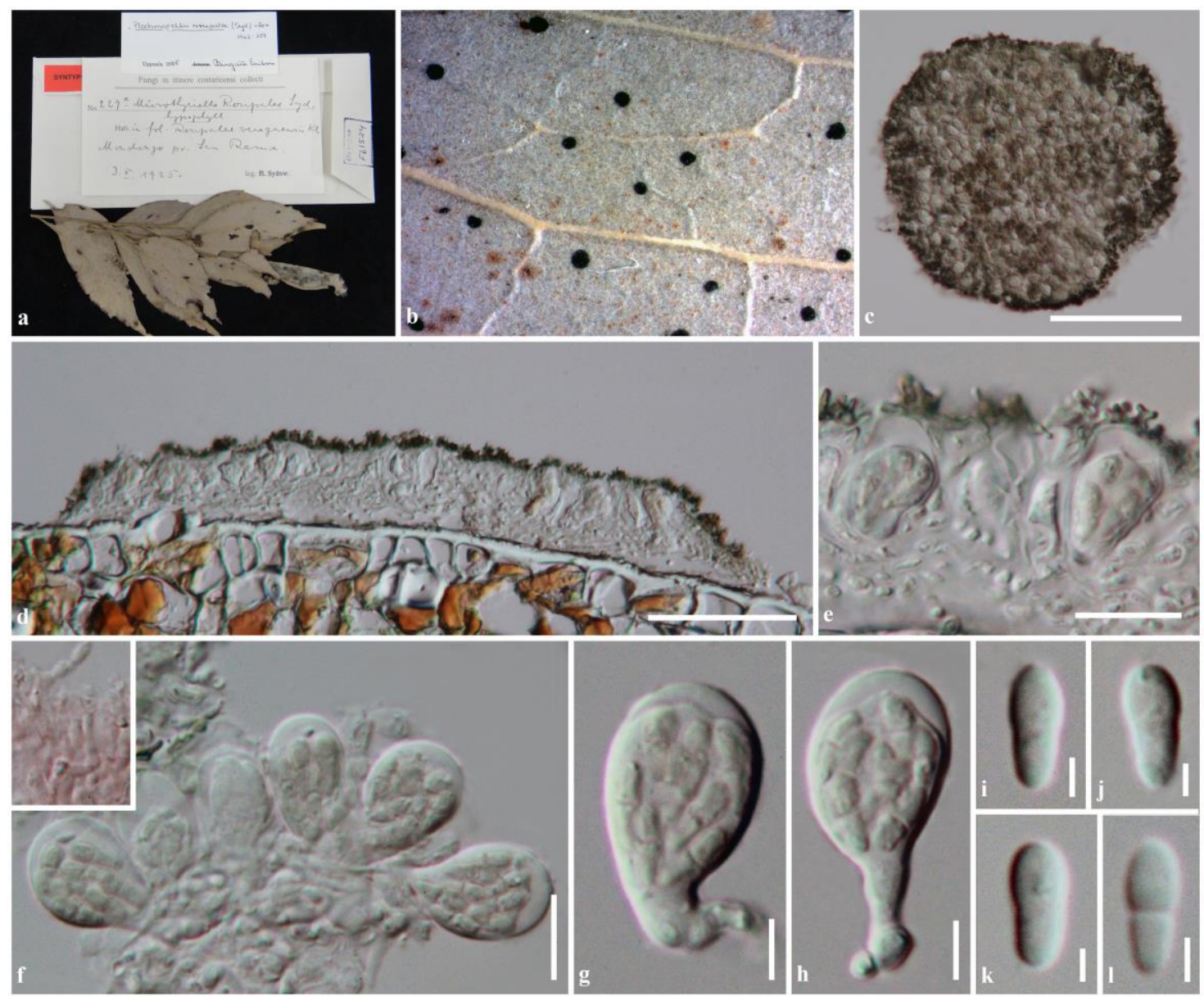

Fig. 7 - Plochmopeltis roupalae (S-F61524, syntype of Microthyriella roupalae Syd.). a. Herbarium label and specimen from S. b. Appearance of ascomata on the host surface. c. Squash mount of ascoma visualized under the compound microscope. d. Section through ascostroma. e. Appearance of the loose mycelium with botryose elements at the apex. f. Asci with paraphysoidlike filaments. g, $\mathrm{h}$. Asci. $\mathrm{i}-1$. Ascospores. Scale bars: $\mathrm{c}=100 \mu \mathrm{m}, \mathrm{d}=50 \mu \mathrm{m}, \mathrm{e}, \mathrm{f}=10 \mu \mathrm{m}, \mathrm{g}, \mathrm{h}=5$ $\mu \mathrm{m}, \mathrm{i}-\mathrm{l}=2 \mu \mathrm{m}$.

Notes - Metathyriella was introduced by Sydow (1927) and is typified by M. roupalae Syd. which was collected from leaves of Roupala veraguensis Klotszch (Proteaceae). The type species was originally described as "ascomata 20-25 $\mu \mathrm{m}$ high, 200-350 $\mu \mathrm{m}$ diam., epiphyllous, thyriothecial, with irregular loose margin, solitary, superficial, dimidiate-scutate, or orbicular, with indistinct basal membrane, the membrane covered by flattened, soft convex layer, softest towards the center, completely closed, irregularly lumpy at maturity, yellowish-brown to olive-brown, later more or less intense, periphery in a subhyaline membrane matrix; hamathecium comprising numerous, filiform, branched, anastomosing, paraphyses; asci 20-28 $\times 17-20 \mu \mathrm{m}, 8$-spored, bitunicate, ellipsoidal, or broadly ovoid to subglobose, sessile to short pedicellate, apically broadly rounded, with an indistinctly attenuate base; ascospores amalgamated, rarely indistinct tri- to tetraseriate, oblong-clavate, gradually tapering towards the base, with obtuse ends, straight or curved, 2septate, distinctly septate at the upper cell, indistinct at the lower cell, or barely constricted, 12-16 $\mu \mathrm{m}$ long, upper cell 5-6 $\mu \mathrm{m}$ wide, subglobose, median cell $5 \mu \mathrm{m}$ wide, subcuboid, obtuse-conoid at the lower cell, and 4-5 $\mu \mathrm{m}$ wide" (Sydow 1927). Sydow (1927) mentioned that the genus was probably related to Clypeolum Speg., but Clypeolum differed from Metathyriella in having multiseptate ascospores.

Sydow (1927) treated the genus in Hemisphaeriaceae, but von Arx and Müller (1975) accommodated the genus in Schizothyriaceae. Various mycologists followed von Arx and Müller (1975) and accommodated Metathyriella in Schizothyriaceae (Eriksson \& Hawksworth 1985, 1987, 
Kirk et al. 2001, 2008, Lumbsch \& Huhndorf 2010, Hyde et al. 2013, Wijayawardene et al. 2014). However, Metathyriella is a poorly studied genus and the type specimen could not be located. Three species are listed in Index Fungorum (2016) and lack molecular data. Hence, the genus needs to recollected and studied.

Myriangiella Zimm., Centbl. Bakt. ParasitKde, Abt. I 8: 183 (1902)

Epiphytic on various flowering plants. Sexual morph: Ascostromata flattened, circular, disciform. Asci 8-spored, bitunicate, ovoid, short pedicellate. Ascospores phragmosporous, hyaline, oblong, septate. Asexual morph: Undetermined (description from Saccardo 1906).

Type species - Myriangiella orbicularis Zimm.

Notes - Myriangiella was introduced by Zimmermann (1902) and is typified by $M$. orbicularis Zimm. which was collected from leaves of coffee (Saccardo 1906). Toro (1927) introduced a new species Myriangiella arcuata Toro from Casearia arculeata Jacq. and was associated with Scolecopeltis micropeltiformis Toro. Myriangiella was treated as a synonym of Micropeltis, named as Micropeltis orbicularis (Zimm.) v. Höhn by von Höhnel (1909a). Later, von Höhnel (1912) excluded the species from Micropeltis in his revision of Micropeltis and treated it in a new genus, Phragmothyriella Höhn. Toro (1927) disagreed with von Höhnel (1909a) as the genus Myriangiella was originally introduced to accommodate this taxon. Hence, Toro (1927) reinstated Myriangiella to accommodate $M$. orbicularis and synonymized Phragmothyriella moelleriana (Sacc.) Höhn. under Myriangiella. Myriangiella moelleriana was treated as Schizothyrium moellerianum (Sacc.) Arx [as 'mollerianum'] by Müller and von Arx (1962).

Limber and Jenkins (1949) transferred Myriangium sabaleos Weedon to Myriangiella as $M$. sabaleos (Weedon) Limber \& Jenkins. However, M. sabaleos has muriform ascospores and does not match with Myriangiella, which has phragmosporous ascospores (Saccardo 1906). Therefore, M. sabaleos need to be recollected to clarify its natural placement. Additionally, von Arx and Müller (1975) transferred Protopeltis roupalae Syd. to the genus Myriangiella in their re-evaluation of bitunicate ascomycetes.

Saccardo (1906) treated Myriangiella in the family Myriangiaceae, while Toro (1927) placed the genus in Hemisphaeriaceae, and von Arx and Müller (1975) accommodated it in Schizothyriaceae. Myriangiella is a poorly studied genus which lacks a modern taxonomic treatment or molecular data to clarify its natural placement. There are only six species reported in Index Fungorum (2016). Myriangiella costaricensis is named Myrianginella costaricensis F. Stevens. which it is mistakenly listed under Myriangiella in Index Fungorum (2016). A type specimen and taxonomic literature for Myriangiella could not be found. Therefore, we treat Myriangiella in Schizothyriaceae, genera incertae sedis.

\section{Genera excluded from Schizothyriaceae}

Amazonotheca Bat. \& H. Maia, in Batista, Publicações Inst. Micol. Recife 56: 408 (1959) Fig. 8 FoF 01943

Epiphytic on leaves of Santiria nitida Merr. and Neea madeirana Standl. Sexual morph: Mycelium lacking. Ascomata scattered, solitary, superficial, dark brown, plane, shield-shaped, orbicular, glabrous, uni-loculate, translucent, membranous, lacking ostioles. Peridium thin-walled, poorly-developed at the base, composed of hyaline, prosenchymatous cells. Hamathecium forming cellular, paraphyses-like filaments, filiform, branched, septate. Asci 4-8-spored, bitunicate, subglobose to ovoid, sessile, apically rounded. Ascospores overlapping, brown, subcylindrical, 2septate, constricted at the septum, smooth-walled. Asexual morph: Undetermined (description from Batista 1959).

Type species - Amazonotheca santiriae Bat. \& H. Maia.

Notes - Amazonotheca was introduced by Batista and Maia, in Batista (1959) to accommodate epiphytic species, having brown, 2-septate ascospores and is typified by Amazonotheca santiriae Bat. \& H. Maia. The type species was collected on leaves of Santiria 
nitida from Brazil which was originally described as "ascomata 25-30 $\mu \mathrm{m}$ high, 420-450 $\mu \mathrm{m}$ diam., sparse on the host, occurred on the top of leaves, dispersed, brown-yellowish, translucent in structure, membranous; peridium 1-5.5 $\mu \mathrm{m}$ wide, comprising hyaline, prosenchymatous cells in the upper walls, margins not fimbriate, poorly-developed at the base; hamathecium $0.5-1 \mu \mathrm{m}$ wide, filiform, branched, septate; asci 13.5-16.5 × 11-13.5 $\mu \mathrm{m}, 4-8$-spored, bitunicate, subglobose to ovoid, sessile; ascospores 11-13.5 × 3-5.5 $\mu \mathrm{m}$, brown, subcylindrical, 2-septate, constricted at the septum, smooth walls" (Fig. 8) (Batista 1959). Batista et al. (1967) accommodated a second species, Amazonotheca olivacea Batista et al. that was collected on leaves of Neea madeirana in Brazil.

Amazonotheca is a poorly known genus that lacks a modern taxonomic treatment and molecular data to resolve its natural placement. There are only two epithets in Index Fungorum (2016) and no sequence data available in GenBank. The type specimen was deposited in the Universidade Federal de Pernambuco (URM), Brazil and could not be loaned. We examined the specimen from Dr. Lima's collection (P-4. Serria do Veado-Serra do Navio, 24 August 1961, Lima J.A.(Leg.), A.C. Batista A.C. \& Xavier Filho L. (det.), URM 28927) and found that the specimen is in poor condition. There are no ascomata of $A$. santiriae on the host surface.

Amazonotheca differs from the generic type, Schizothyrium in forming anastomosing, cellular pseudoparaphyses and has a peridium of prosenchymatous cells. Schizothyrium forms network-like filaments and has a peridium composed of pseudoparenchymatous cells, arranged in textura angularis to textura globulosa. Amazonotheca is similar to Hexagonella in having brown, 2-septate ascospores. However, Amazonotheca differs from Hexagonella in having brownyellowish, translucent, membranous ascomata, with asci forming among pseudoparaphyses from the base, while Hexagonella has naked ascomata, comprising loose, branched, spreading hyphae and asci formed in a space between the hexagonal, mesh-like structure. We therefore, exclude Amazonotheca from Schizothyriaceae and place the genus in Dothideomycetes, genera incertae sedis. Nevertheless, recollection and molecular data of Amazonotheca is needed to resolve its natural placement of the genus.

Chaetoplaca Syd. \& P. Syd., Annls mycol. 15(3/4): 232 (1917) FoF 01944

$\equiv$ Acanthoderma Syd. \& P. Syd., Annls mycol. 15(3/4): 234 (1917)

Epiphytic, on lower surface of leaves of Memecylon sp. Sexual morph: Undetermined. Asexual morph: Conidiomata acervular, scattered to clustered, solitary to gregarious, superficial, dark brown to black, circular or irregular in shape, producing orangish-brown areas around the conidiomata on its host tissue, plane, with a single stratum, uni-loculate, setose, membranous, lacking ostioles. Peridium thin-walled, composed of light brown to brown, irregular meandering arrangement of compact cells. Setae reddish-brown to dark brown, erect, aseptate. Conidiophores reduced to conidiogenous cells. Conidiogenous cells phialidic, holoblastic, determinate, short, indistinct to ampulliform, hyaline, smooth-walled, restricted to the base. Conidia solitary, clavate to falcate, hyaline to subhyaline, initially aseptate, becoming 2 -septate at maturity, base truncate, rough and thick-walled.

Type species - Chaetoplaca memecyli Syd. \& P. Syd.

Notes - Chaetoplaca was introduced as a monotypic genus by Sydow and Sydow (1917) to accommodate $C$. memecyli Syd. \& P. Syd. which was collected on leaves of Memecylon sp. in the Philippines. The genus is poorly known, has a single species and lacks sequence data. Sydow and Sydow (1917) found both the sexual and asexual morph associated with the host and described the sexual morph of $C$. memecyli as "ascomata 1-2 mm diam., on lower surface of leaves, depressed, superficial, orbicular, pale brown to black, subhyaline at the margin, with a single stratum, membranous, composed of radiating cells, lacking paraphyses; asci 50-65 × 16-19 $\mu \mathrm{m}, 8$-spored, bitunicate, clavate, subsessile to short pedicellate, apically rounded; ascospores 16-18 $\times 7-8 \mu \mathrm{m}$, initially hyaline, becoming brown at maturity, obovoid-ellipsoidal to ovoid-oblong, apically rounded, with rounded to attenuated at the base, 1-septate, slightly constricted at the septum". 

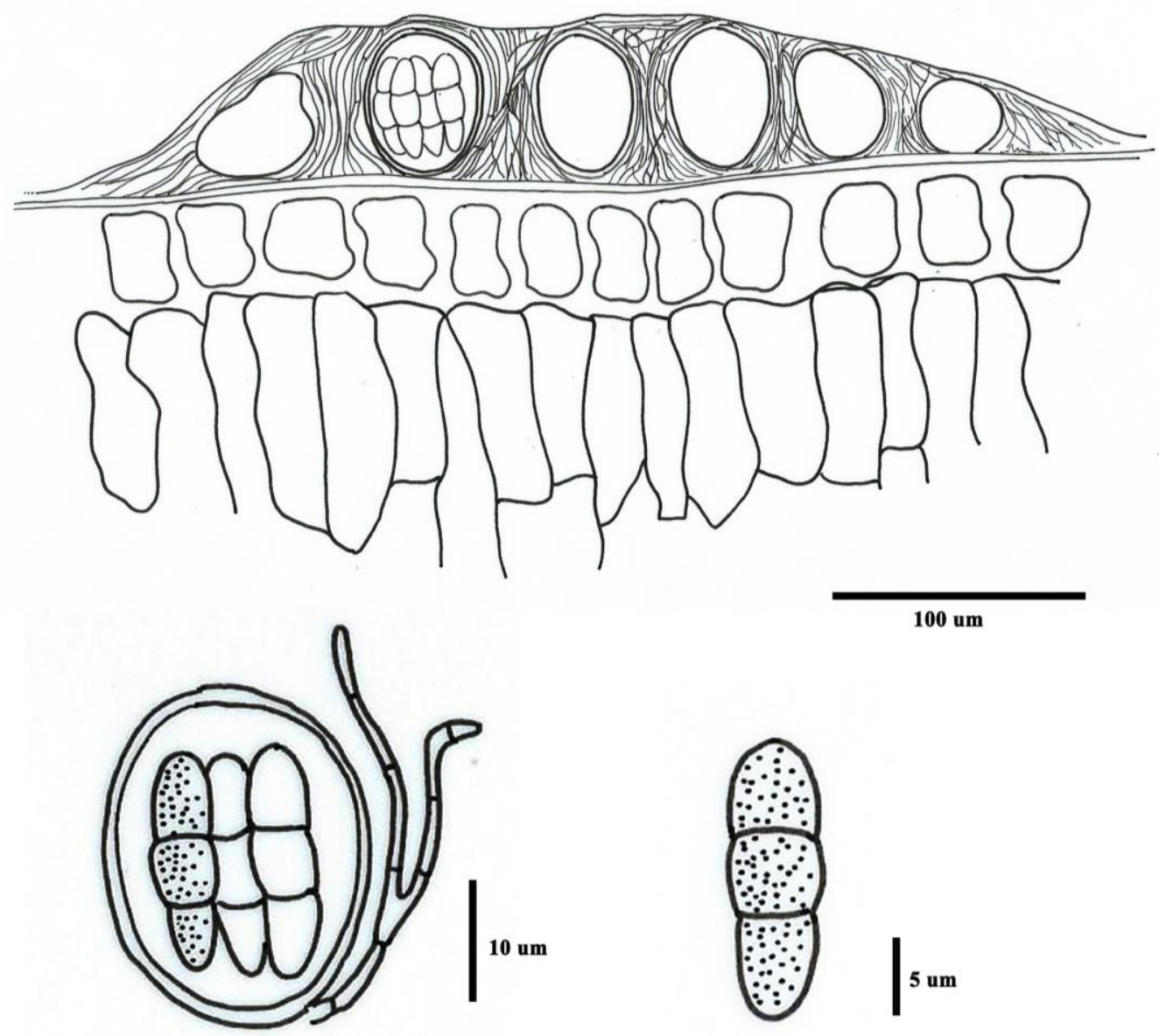

Fig. 8 - Amazonotheca santiriae (redrawn from Batista A.C. (1959), iconotype). a. Section through ascomata $\mathrm{b}$. Ascus with pseudoparaphyses. c. Ascospore. Scale bars: $\mathrm{a}=100 \mu \mathrm{m}, \mathrm{b}=10$ $\mu \mathrm{m}, \mathrm{c}=5 \mu \mathrm{m}$.

Sydow and Sydow (1917) mentioned that the asexual morph of $C$. memecyli was found on top of the ascomata forming fusarium-like conidia $(17-20 \times 2.5-3.5 \mu \mathrm{m})$ and introduced it as Acanthoderma memecyli Syd.

Chaetoplaca was initially accommodated in Hemisphaeriaceae by Sydow and Sydow (1917). Later, Müller and von Arx (1962) placed the genus in Schizothyriaceae and this was followed by various authors (von Arx \& Müller 1975, Barr 1979, Eriksson \& Hawksworth 1985, 1987, Kirk et al. 2001, 2008, Lumbsch \& Huhndorf 2010, Hyde et al. 2013, Wijayawardene et al. 2014).

We examined the type specimen of Chaetoplaca memecyli from BPI and could not find the sexual morph. A vertical section through the conidiomata, C. memecyli showed a plane, single stratum, setose conidiomata with falcate conidia and no sexual morph. We therefore accommodate Chaetoplaca as coelomycetous in Ascomycetes, genera incertae sedis.

Chaetoplaca memecyli Syd. \& P. Syd., Annls mycol. 15(3/4): 232 (1917)

Fig. 9, 10 FoF 01945

= Acanthoderma memecyli Syd. \& P. Syd., Annls mycol. 15(3/4): 234 (1917)

Epiphytic, occurred on the lower surface of leaves of Memecylon sp. Sexual morph: Undetermined. Asexual morph: Conidiomata 1-2 mm diam., acervular, scattered to clustered, solitary to gregarious, superficial, dark brown to black, circular or irregular in shape, producing orangish-brown areas around conidiomata on host tissue, plane, with a single stratum, uni-loculate, setose, membranous, lacking ostioles. Peridium 3-10 $\mu \mathrm{m}$ wide, thin, composed of light brown to 
brown, irregular meandering arrangement of compact cells. Setae 30-50 $\mu \mathrm{m}$ high, reddish-brown to dark brown, erect, aseptate, arising from the basal walls. Conidiophores reduced to conidiogenous cells. Conidiogenous cells phialidic, holoblastic, determinate, short, indistinct ampulliform, hyaline, smooth-walled, restricted to the base. Conidia (15-)18-22 (-25) $\times(5-) 6-8 \mu \mathrm{m}(\bar{x}=19.7 \times 4.7 \mu \mathrm{m}$, $\mathrm{n}=30$ ), solitary, clavate to falcate, hyaline to subhyaline, initially aseptate, becoming 2 -septate at maturity, narrow and truncate at the base, with rough and thick-walled.

Material examined - PHILIPPINES, Bataan Prov., Luzon, on leaves of Memecylon sp., December 1915, M. Ramos, BPI 619031, type.
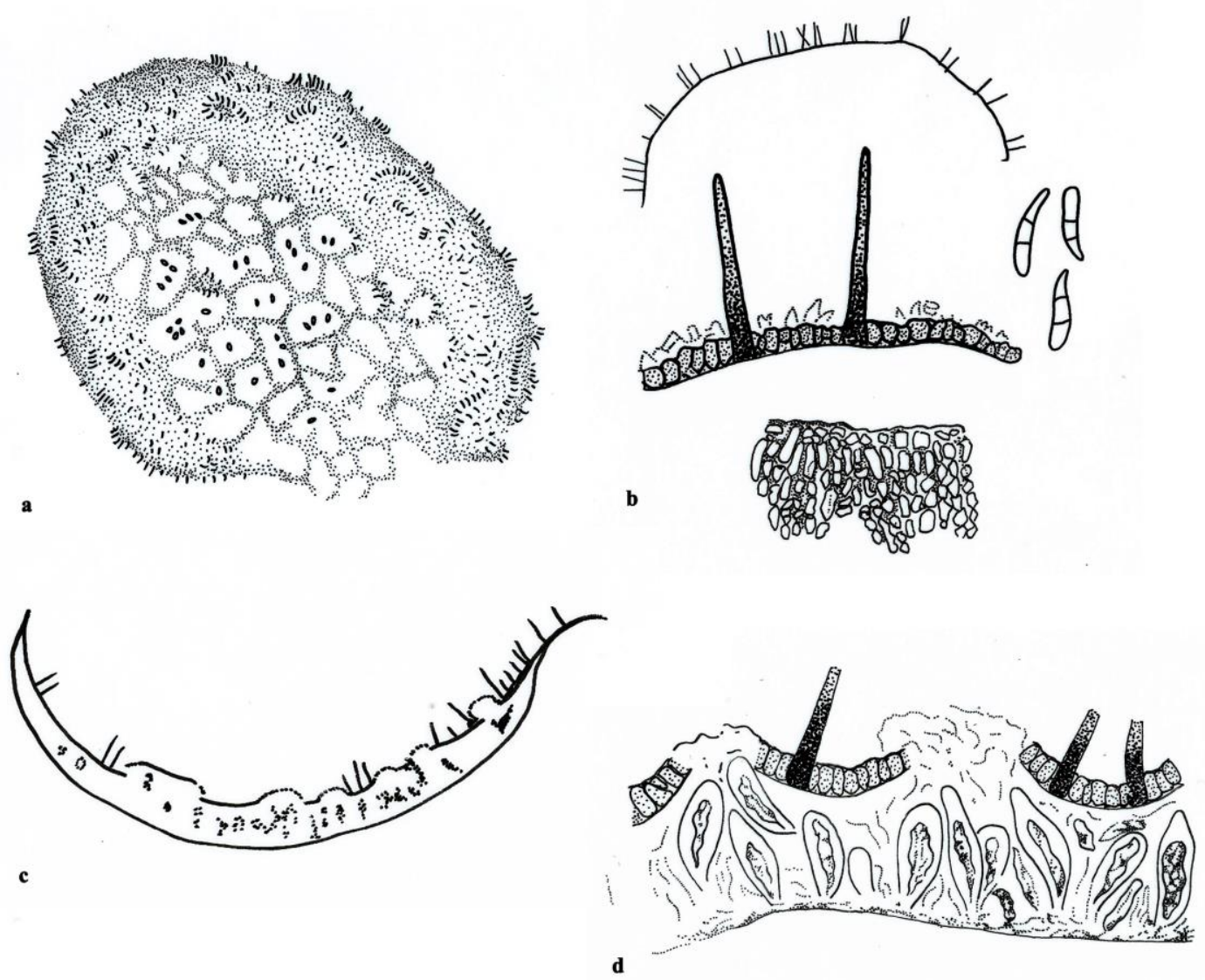

Fig. 9 - Chaetoplaca memecyli (redrawn from Sydow and Sydow (1917), iconotype). a. Appearance of conidiomata on the host. b. Cross-sections through the conidioma. c. Setae arising from the base of conidioma. d. A part of the membrane bearing conidia. e. Conidia. f. Cross-section through the membrane. g. Asci appearing in conidiomata.

Henningsiella Rehm, Hedwigia 34(Beibl.): (160) (1895) FoF 01946

Epiphytic, on the upper surface of leaves of Cordia, Cryptomeria and Ilex, or on the rotten wood. Sexual morph: Ascostromata scattered, solitary to gregarious, superficial, brown to dark brown or black, circular or irregular in shape, rounded, soft or fleshy, discoid, multi-loculate, glabrous, membranous, lacking ostioles. Peridium thin-walled, composed of light brown to brown, loose, isodiametrical or radiating cells, arranged in a textura angularis to textura prismatica. Asci 8-spored, bitunicate, fissitunicate, clavate, subsessile to short pedicellate, apically rounded, with a well-developed ocular chamber, embedded on mucilaginous matrix. Ascospores overlapping, uni- 
to bi-seriate, hyaline, oblong to ellipsoidal, or clavate with rounded ends, septate or aseptate, smooth-walled with small guttules. Asexual morph: Undetermined.

Type species - Henningsiella quitensis Rehm

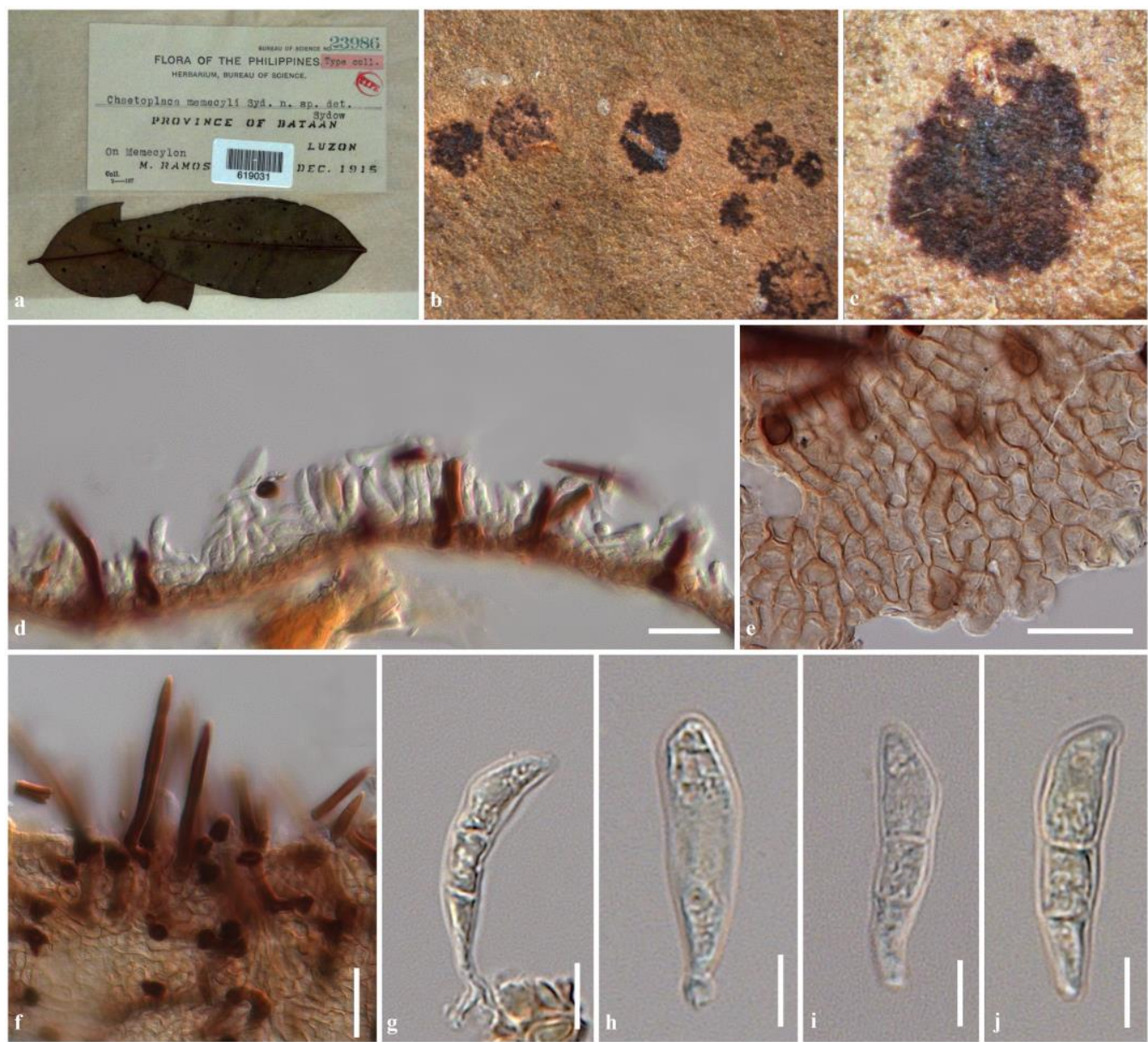

Fig. 10 - Chaetoplaca memecyli (BPI623579, type). a. Herbarium label and specimen of Chaetoplaca memecyli. b, c. Appearance of conidiomata on the host surface. d. Sections through conidioma. e. Peridium structure visualized from above. f. Setae covering conidiomata. g. Conidiogenesis cell. $\mathrm{h}-\mathrm{j}$. Conidia. Scale bars: $\mathrm{d}$, $\mathrm{e}=20 \mu \mathrm{m}, \mathrm{f}=10 \mu \mathrm{m}, \mathrm{g}-\mathrm{j}=5 \mu \mathrm{m}$.

Notes - Henningsiella was introduced as a monotypic genus by Rehm (1895) and typified by $H$. quitensis Rehm. The species was previously identified as Ascomycetella quitensis Pat., in Patouillard and de Lagerheim (1895) and accommodated in Phymatosphaeriaceae Speg. (1888), because of its apothecial, gregarious, sessile ascomata (Rehm 1895). Rehm (1895) mentioned that Ascomycetella has ovate-oblong, multi-septate, muriform ascospores, and is different from Ascomycetella quitensis which has 2-celled ascospores. Therefore, Rehm (1895) introduced Henningsiella to accommodate Ascomycetella quitensis. The original description is "ascostromata apothecial, epiphyllous, gregarious, sessile, initially globose, becoming plane, dish-like to convex, grey-hyaline, with a distinct margin, gelatinous, parenchymatous, lacking paraphyses; asci 8spored, bitunicate, clavate, apically rounded, embedded in the gelatinous; ascospores cuneiform, 2celled, hyaline. Subsequently, Rehm (1909) introduced the second species, H. fairmanii Rehm. Sawada (1959) also introduced H. cryptomeriae which was collected on Cryptomeria from Taiwan.

Based on morphological characters, Müller and von Arx (1962) accommodated Henningsiella in Schizothyriaceae and transferred Bulgariastrum cordiae Bat. to Henningsiella as H. cordiae (Bat.) Arx. Various mycologists followed Müller and von Arx (1962) such as von Arx and Müller (1975), Kirk et al. (2008), Lumbsch and Huhndorf (2010), Hyde et al. (2013), Wijayawardene et al. (2014). Nevertheless, the genus Henningsiella is relatively poorly known 
genus with four species in Index Fungorum (2016) and these lack molecular data. Hence, the genus needs recollecting.

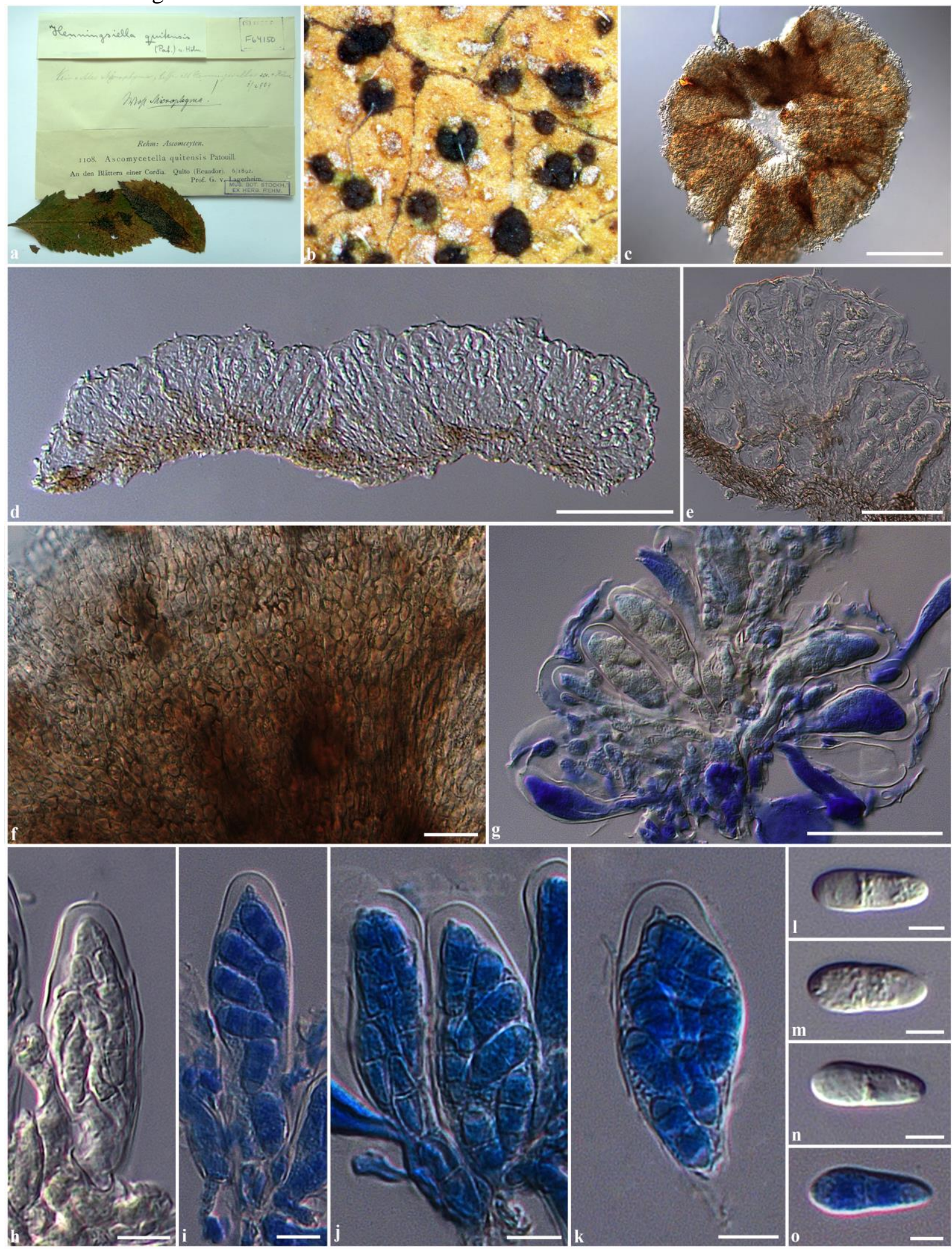

Fig. 11 - Henningsiella quitensis (S-F64150, type of Ascomycetella quitensis). a. Herbarium specimen from S. b. Appearance of ascostromata on the host surface. c. Squash mount of ascostroma visualized under the compound microscope. d. Section through ascostroma. e. Section through peridium. f. Peridium structure visualized from above. g. Asci lacking pseudoparaphyses stained in cotton blue. h. Ascus. i-k. Asci stained in cotton blue. 1-n. Ascospores. o. Ascospore 
stained in cotton blue. Scale bars: $\mathrm{c}=200 \mu \mathrm{m}, \mathrm{d}=100 \mu \mathrm{m}, \mathrm{g}=50 \mu \mathrm{m}, \mathrm{e}, \mathrm{f}=20 \mu \mathrm{m}, \mathrm{h}-\mathrm{k}=10 \mu \mathrm{m}$, $1-0=5 \mu \mathrm{m}$.

In this study, we examine the generic type of Henningsiella and found that the genus is related to Saccardiaceae rather than Schizothyriaceae as it has apothecia, with thick walls at the base. Therefore, we exclude the genus from Schizothyriaceae and place the genus in Saccardiaceae, until the molecular phylogeny is obtained to resolve its natural placement.

Henningsiella quitensis Rehm, Hedwigia 34(Beibl.): (159) (1895)

Fig. 11 FoF 01947

इAscomycetella quitensis Pat., in Patouillard \& Lagerheim, Bull. Soc. mycol. Fr. 11(4): 231 (1895)

Epiphytic, on the upper surface of leaves of Cordia. Sexual morph: Ascostromata 115-185 $\mu \mathrm{m}$ high, 460-550 $\mu \mathrm{m}$ diam., scattered, solitary to gregarious, superficial, brown to dark brown or black, circular or irregular in shape, rounded, soft or fleshy, discoid, multi-loculate, glabrous, membranous, lacking ostioles. Locules $70-160 \mu \mathrm{m}$ diam., clustered, quadrilateral, flabelliform, or irregular in shape in vertical section, each locule separated by thin, light brown membranous cells. Peridium thin-walled, of unequal thickness, poorly-developed at the apex (2-6 $\mu \mathrm{m}$ wide), thicker at the base (15-30 $\mu \mathrm{m}$ wide) composed of light brown to brown, loose, isodiametrical or radiating cells, arranged in a textura angularis to textura prismatica. Asci $(32-) 45-55(-60) \times(13-) 14-17(-$ 19) $\mu \mathrm{m}(\bar{x}=50.7 \times 15.9 \mu \mathrm{m}, \mathrm{n}=25), 8$-spored, bitunicate, fissitunicate, clavate, subsessile to short pedicellate, apically rounded with well-developed ocular chamber, embedded on mucilaginous matrix. Ascospores 13-15 $\times(4-) 5-7 \mu \mathrm{m}(\bar{x}=14.3 \times 5.8 \mu \mathrm{m}, \mathrm{n}=25)$, overlapping uni- to biseriate, hyaline, oblong to ellipsoidal, or clavate with rounded ends, 1 -septate, not constricted at the septum, smooth-walled with small guttules. Asexual morph: Undetermined.

Material examined - ECUADOR, Quito on the leaves of Cordia, June 1892, von Lagerheim G. in Rehm's exsiccata, Ascomyc. nr. 1108, F64150, type of Ascomycetella quitensis Pat.

Notes - Henningsiella quitensis differs from $H$. fairmanii in lacking pseudoparaphyses which asci embedded in mucilaginous matrix, while $H$. fairmanii has filiform pseudoparaphyses (Rehm 1909). Henningsiella quitensis differs from $H$. cordiae due to its larger ascostromata (Müller \& von Arx 1962).

Hysteropeltella Petr., Annls mycol. 21(1/2): 9 (1923)

FoF 01948

Saprobic on stems of Aspidium filix-mas (Linn.) Swartz. Sexual morph: Ascomata elongate apothecial, whitish-grey, superficial, scattered, solitary, elongate ellipsoidal, apothecial or hypothecia-like, glabrous, coriaceous, with longitudinal slit-like opening. Peridium thin, composed of two layers of brown to dark brown pseudoparenchymatous cells, arranged in a textura angularis. Asci 8-spored, bitunicate, fissitunicate, broadly oblong to ellipsoidal, or clavate, sessile to subsessile, thick at the apex, apically rounded, with plane apex, asci apex tuning blue when stained by Melzer's reagent. Ascospores overlapping irregular-seriate, initially hyaline, eventually becoming pale brown, clavate-oblong to fusoid, or ellipsoidal, with slightly rounded ends, 1septate, slightly constricted at the septum, smooth-walled, surrounded by a thin, distinct mucilaginous sheath. Asexual morph: Undetermined (description from Petrak 1923, Ariyawansa et al. 2013).

Type species - Hysteropeltella moravica Petr.

Notes - Hysteropeltella was introduced by Petrak (1923) to accommodate a single species, H. moravica Petr. which was collected on a dead stem of Aspidium filix-mas (Linn.) Swartz from the Czech Republic. Holm and Holm (1978) revised the genus and mentioned that the asci of $H$. moravica turn blue at the apex, when stained in Melzer's reagent (Ariyawansa et al. 2013). Petrak (1923) mentioned that Hysteropeltella formed pseudoparaphyses among the asci. Holm and Holm (1978) however, did not mention this character. Due to the inconspicuous morphology with hysterothecia, lying on the host and opening via a longitudinal slit, Holm and Holm (1978) treated 
the genus in the discomycetes, while Lumbsch and Huhndorf (2010) placed the genus in Dothideomycetes, genera incertae sedis.

Ariyawansa et al. (2013) examined the type specimen of Hysteropeltella moravica. In their examination, the ascospores were often hyaline, eventually turning light brown at maturity and asci turned blue when stained in Melzer's reagent. Pseudoparaphyses were observed by Ariyawansa et al. (2013); this may depend on the maturity of ascomata (Ariyawansa et al. 2013). Based on the hysterothecial ascomata with longitudinal slit-like opening, similar to Linopeltis, Ariyawansa et al. (2013), therefore, treated Hysteropeltella in the family Schizothyriaceae and this was followed by Wijayawardene et al. (2014).

Nevertheless, we exclude the genus Hysteropeltella from Schizothyriaceae due to its ascomatal structures which form elongated apothecial or hypothecia-like ascomata (see Ariyawansa et al. 2013), similar to the genus Baggea in Patellariaceae (Yacharoen et al. 2015). Therefore, we tentatively place the genus in Patellariaceae, however fresh collections are needed to resolve its natural placement.

Linopeltis I. Hino \& Katum., J. Jap. Bot. 36: 99 (1961) FoF 01949

Epiphytic on branches of bamboo. Sexual morph: Ascostromata scattered, solitary to gregarious, superficial, elongate ellipsoidal or furcate, to triangular, dark brown to black, hemisphaerical, or shield-shaped, shiny, glabrous, multi-loculate, with slit-like opening. Locules clustered, globose to subglobose. Peridium thin-walled, poorly-developed at the base, composed of dark brown to black pseudoparenchymatous cells, arranged in a textura epidermoidea. Hamathecium composed of dense, anastomosing, filamentous, cellular pseudoparaphyses. Asci 8spored, bitunicate, oblong to ellipsoidal, short pedicellate, apically rounded, with indistinct ocular chamber. Ascospores overlapping, fasciculate, initially hyaline, becoming brown at maturity, cylindrical to elongated fusoid, with slightly rounded ends, distoseptate, 6-10-septate, thick and smooth-walled. Asexual morph: Undetermined.

Type species - Linopeltis ryukyuensis I. Hino \& Katum.

Notes - Linopeltis was introduced by Hino and Katumoto (1961) to accommodate a bambusicolous species forming hysterothecial-like ascomata with slit-like openings, oblong to ellipsoidal asci and elongated fusiform to cylindrical, distoseptate ascospores. The genus is typified by L. ryukyuensis I. Hino \& Katum. which was collected from Japan. Hino and Katumoto (1961) mentioned that the genus lacked pseudoparaphyses, while these were observed in our examination. Von Arx and Müller (1975) treated the genus in Schizothyriaceae and this was subsequently followed (Kirk et al. 2008, Lumbsch \& Huhndorf 2010, Hyde et al. 2013, Wijayawardene et al. 2014).

Linopeltis is similar to the genera in Asterinaceae and Aulographaceae in having elongated hysterothecial-like ascomata with slit-like openings (Hyde et al. 2013, Hongsanan et al. 2014). However, Linopeltis differs from Asterinaceae in ascostromata having pseudoparenchymatous cells, not radiating cells and lacking appressoria. Linopeltis differs from Aulographaceae in having multi-distoseptate ascospores, while species in Aulographaceae having only 1-septate ascospores. Although, Linopeltis may belong in Aulographaceae, we however, tentatively place the genus in Dothideomycetes, genera incertae sedis based on its morphology.

Linopeltis ryukyuensis is a poorly understood species which lacks a modern taxonomic description and molecular data is needed to resolve its natural placement. Recollection is needed, to obtain molecular work to clarify its natural placement.

Linopeltis ryukyuensis I. Hino \& Katum., J. Jap. Bot. 36: 100 (1961)

Fig. 12 FoF 01950

Epiphytic on branches of Sinobambusa tootsik Makino and Pleioblastus linearis (Hack.) Nakai. Sexual morph: Ascostromata 60-100 $\mu \mathrm{m}$ high, 300-820 $\mu \mathrm{m}$ long, 180-230 $\mu \mathrm{m}$ diam., scattered, solitary to gregarious, superficial, elongate ellipsoidal or furcate, to triangular, dark 
brown to black, shiny, glabrous, multi-loculate, with slit-like opening. Locules $60-100 \mu \mathrm{m}$ high, 50-100 $\mu \mathrm{m}$ diam., clustered, immersed on ascostroma, globose to subglobose, discharging asci and
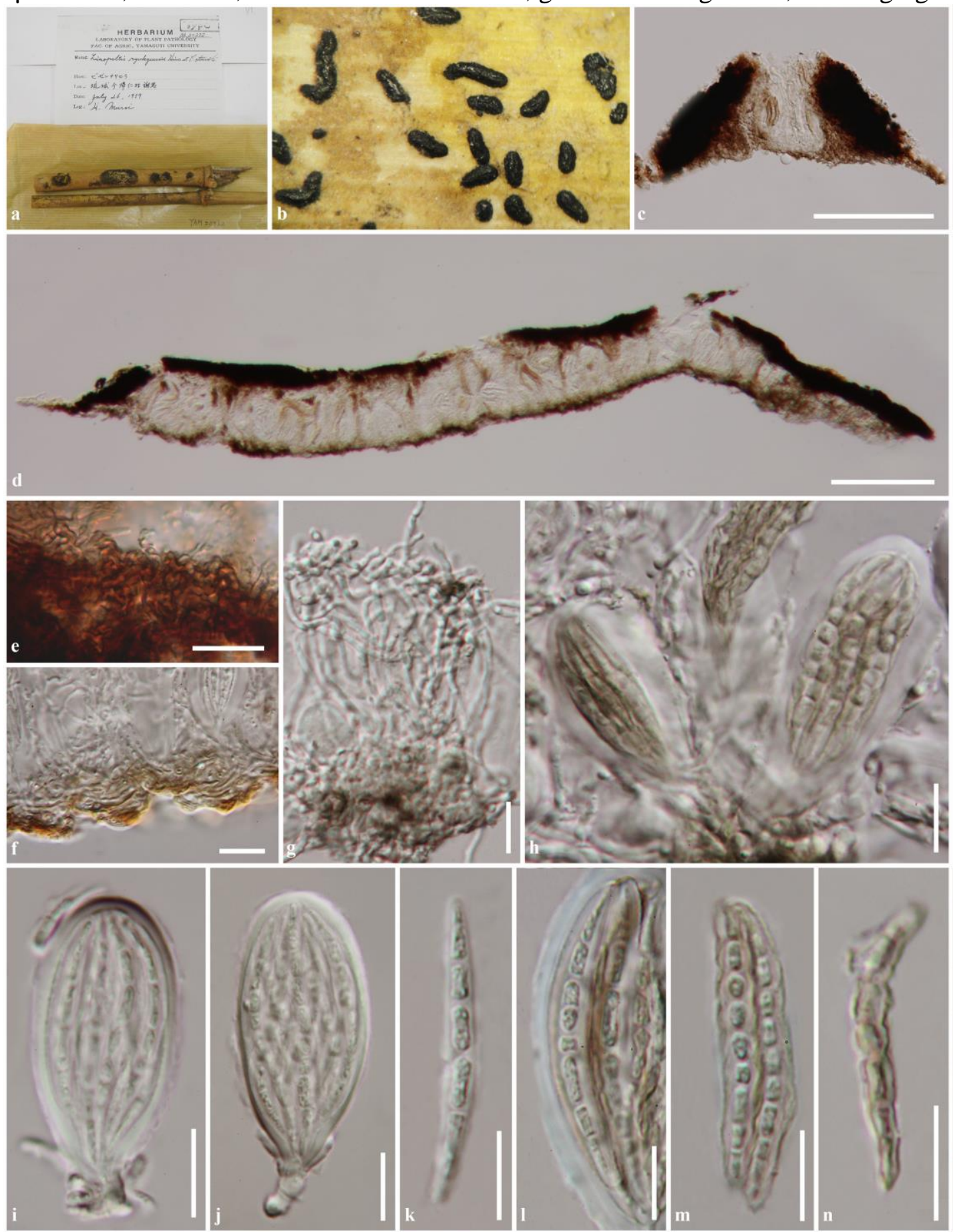

Fig. 12 - Linopeltis ryukyuensis (YAM 20332, holotype). a. Label and specimens from YAM. b. Appearance of ascostromata on the host surface. c, d. Sections through ascostromata. e, f. Section through peridium. g. Pseudoparaphyses. h. Asci embedded in pseudoparaphyses. i, j. Asci. k-n. Ascospores. Scale bars: c, $d=100 \mu \mathrm{m}, \mathrm{e}-\mathrm{m}=10 \mu \mathrm{m}$.

ascospores via a longitudinal slit. Peridium 9-20 $\mu \mathrm{m}$ wide, thin-walled, poorly-developed at the base, composed of dark brown to black pseudoparenchymatous cells, arranged in a textura epidermoidea. Hamathecium composed of dense, 1-1.5 $\mu \mathrm{m}$ wide, anastomosing, filamentous, cellular pseudoparaphyses. Asci (40-)45-58(-65) $\times(19-) 20-25 \mu \mathrm{m}(\bar{x}=53.8 \times 22.5 \mu \mathrm{m}, \mathrm{n}=20)$, 8 -spored, bitunicate, oblong to ellipsoidal, short pedicellate, apically rounded with indistinct ocular 
chamber. Ascospores (26-)30-40 × 3-4 $\mu \mathrm{m}(\bar{x}=35.1 \times 3.6 \mu \mathrm{m}, \mathrm{n}=25)$, overlapping, fasciculate, initially hyaline, becoming brown at maturity, cylindrical to elongate fusoid, slightly rounded ends, distoseptate, 6-10-septate, thick and smooth-walled. Asexual morph: Undetermined.

Material examined - JAPAN, Okinawa, Nakijinson, Jana Kunigamaigun, on branch of Sinobambusa tootsik (Poaceae), 26 July 1959, H. Muroi, YAM 20332, holotype.

Mendogia Racib., Parasit. Alg. Pilze Java's (Jakarta) 3: 31 (1900) FoF 01951

Epiphytic on living bamboo. Sexual morph: Ascostromata scattered, solitary to gregarious, superficial on host surface, black, flattened, circular to round with concave edge, easily removed from the host, hemisphaerical or shield-shaped to rugulose, uni- to multi-loculate, glabrous, walls rough, carbonaceous at the outer surface. Locules clustered, immersed in ascostroma, globose to subglobose, or hemisphaerical, with individual ostioles, or discharging asci and ascospores via the breaking of the outer walls. Peridium thick-walled, composed of two layers, outer layer comprising thick, carbonaceous, melanized cells, arranged in a textura angularis, inner layer comprising thick, brown to dark brown, pseudoparenchymatous cells, arranged in textura angularis. Hamathecium composed of dense, anastomosing, septate, paraphysoid-like filaments. Asci 8-spored, bitunicate, fissitunicate, cylindric-clavate to clavate, short pedicellate, apically rounded, with an ocular chamber, thick at the apex. Ascospores overlapping, uni- to tri-seriate, hyaline, ellipsoidal to clavate, muriform, constricted at the septum, smooth-walled. Asexual morph: Undetermined.

Type species - Mendogia bambusina Racib.

Notes - Mendogia was introduced by Raciborski (1900) and typified by M. bambusina which was collected on bamboo in Indonesia. Mendogia is a relatively poorly known genus, which was collected on the bamboo, Dinochloa and Schizostachyum and palms from Indonesia and Philippines in South East Asia (Farr \& Rossman 2015). Three species are listed in Index Fungorum (2016) and molecular data is lacking in GenBank. Von Arx and Müller (1975) treated Mendogia in the family Schizothyriaceae and synonymized Uleopeltis manaosensis P. Henn and Pleiostomella philippinensis Syd. under the genus Mendogia. This was subsequently followed by Kirk et al. (2008), Lumbsch and Huhndorf (2010), Hyde et al. (2013) and Wijayawardene et al. (2014).

Mendogia differs from other genera in Schizothyriaceae in having large ascostromata; a thick peridium, carbonaceous at the outer walls, with inner layers comprising pseudoparenchymatous cells, and muriform ascospores. Species of Schizothyriaceae have small ascomata, with thin, membranous walls and didymosporous ascospores. Mendogia was recently treated in the family Myriangiaceae, Myriangiales based on its phylogenetic study (see the details in Dai et al. 2016). Therefore, we exclude Mendogia from Schizothyriaceae.

Neopeltella Petr., Sydowia 4(1-6): 329 (1950)

FoF 01952

Epiphytic on the lower surface of leaves of Bambusa spp. Sexual morph: Ascomata thyriothecial, scattered, solitary, superficial on host surface, dark brown to black, flattened, black spots on the host surface, easily removed from the host, hemisphaerical or shield-shaped, uniloculate, glabrous, ostiolate, with irregular openings. Peridium thick-walled, composed of two types of layers, an irregular meandering arrangement of compact hyphae, outer layer comprising thin, brown to dark brown cells, arranged in a textura intricata, inner layer comprising thick, hyaline to light brown cells, arranged in textura prismatica to textura porrecta. Asci 8-spored, bitunicate, fissitunicate, ovoid to saccate, or ampulliform, sessile to subsessile, apically rounded, with an ocular chamber, embedded in mucilaginous matrix. Ascospores overlapping, tetra- to penta-seriate, hyaline to subhyaline, cylindrical, with rounded ends, 11-12-septate, constricted at the septum, rough-walled. Asexual morph: Undetermined.

Type species - Neopeltella aequatoriensis Petr.

Notes - Neopeltella was introduced as a monotypic genus by Petrak (1950b) and is typified by $N$. aequatoriensis Petr. which was collected on bamboo in Ecuador. Neopeltella is similar to 
Micropeltis Mont. (= Scolecopeltella Speg.) in having dimidiate-scutate, orbicular ascomata, with pore-like openings and phragmosporous ascospores (Petrak 1950b). However, Neopeltella differs from Micropeltis due to its peridium structures comprising dark brown cells and hyaline, cylindrical ascospores (Petrak 1950b). Micropeltis often has peridium structures with bluish-green cells, with an irregular meandering arrangement (Petrak 1950b, Wu et al. 2011, Hyde et al. 2013). Petrak (1950b) mentioned that Neopeltella lacks pseudoparaphysoids, but there are eventually present and strongly shriveled or very slimy when mature.

Neopeltella is a poorly understood, with a single species listed in Index Fungorum (2016) and no sequence data is available in GenBank. Von Arx and Müller (1975) treated the genus in Schizothyriaceae according to its epiphytic habitat and this was followed by various mycologists (Barr 1979, Kirk et al. 2008, Lumbsch \& Huhndorf 2010, Hyde et al. 2013, Wijayawardene et al. 2014).

Hyde et al. (2013) re-circumscribed the family Micropeltidaceae and mentioned that Micropeltidaceae differs from Microthyriaceae in having bluish-green thyriothecial, comprising cells in a meandering arrangement and long, clavate ascospores with mostly more than two transverse septa. Therefore, Neopeltella is placed in Micropeltidaceae due to its thyriothecia, with multi-septate ascospores.

Neopeltella aequatoriensis Petr., Sydowia 4(1-6): 329 (1950) FoF 01953

Fig. 13

Epiphytic on the lower surface of leaves of Bambusa sp. Sexual morph: Ascomata 300-490 $\mu \mathrm{m}$, thyriothecial, scattered, solitary, superficial on host surface, dark brown to black, flattened, black spots on the host surface, easily removed from the host, hemisphaerical or shield-shaped, uniloculate, glabrous, ostiolate with irregular openings. Peridium thick-walled, composed of two types of layers, an irregular meandering arrangement of compact hyphae, outer layer 6-12 $\mu \mathrm{m}$ wide, comprising thin, brown to dark brown cells, arranged in a textura intricata, inner layer 20-60 $\mu \mathrm{m}$ wide, comprising thick, hyaline to light brown cells, arranged in textura prismatica to textura porrecta. Asci (48-)50-70 × 30-45(-56) $\mu \mathrm{m}(\bar{x}=62.1 \times 39.7 \mu \mathrm{m}, \mathrm{n}=20)$, 8-spored, bitunicate, fissitunicate, ovoid to saccate, or ampulliform, sessile to subsessile, apically rounded with ocular chamber, embedded mucilaginous sheath. Ascospores $(48-) 50-70(-79) \times 5-7(-10) \mu \mathrm{m}(\bar{x}=58.6 \times$ $7.2 \mu \mathrm{m}, \mathrm{n}=30$ ), overlapping, tetra- to penta-seriate, hyaline to subhyaline, cylindrical, with rounded ends, 11-12-septate, constricted at the septum, rough-walled. Asexual morph: Undetermined.

Material examined - ECUADOR, Pichincha, Mindo, on Bambusa sp. (Poaceae), 24 October 1937, H. Sydow, S-F10295, type; ibid. W Krypto 1992-0005916, type.

Orthobellus A.A. Silva \& Cavalc., in Silva et al., Publicações Inst. Micol. Recife 691: 4 (1973)

FoF 01954

Epiphytic on the lower surface of leaves of Leguminosae and Lauraceae. Sexual morph: Mycelium abundant, superficial, bristles (tufts), not hyphopodiate, with simple setae, straight or curved. Ascomata scattered, solitary, flattened, brown, orbicular, superficial, uni-loculate, setose, membranous, lacking ostioles. Peridium composed of the meandering arrangement of compact hyphae, thin-walled at the base. Hamathecium composed of dense, filamentous, anastomosing, cellular pseudoparaphyses. Asci 8-spored, bitunicate, clavate, sessile. Ascospores hyaline, clavate, 1-septate, not constricted at the septum, smooth-walled. Asexual morph: Undetermined (description from Silva et al. 1973)

Type species - Orthobellus leguminosarum A.A. Silva \& Cavalc.

Notes - Orthobellus was introduced by Silva et al. (1973) and typified by $O$. leguminosarum which was collected on leaves of Leguminosae in Brazil. Silva et al. (1973) accommodated two species in this genus viz. Orthobellus lauracearum (Bat. \& T. Herrera) Cavalc. $\&$ A. A. Silva and O. leguminosarum. The generic type was originally described as "Colonies $0.3-2$ 
cm diam., hypophyllous; ascomata 92-170 $\mu \mathrm{m}$ diam., orbicular, setose, membranous; asci 22-30 $\times$ 12-17 $\mu \mathrm{m}, 8$-spored, bitunicate, clavate, sessile, with cellular pseudoparaphyses; ascospores 9.5$12.5 \times 2.5-3.5 \mu \mathrm{m}$, hyaline, clavate, 1-septate, smooth-walled" (Silva et al. 1973). Silva et al. (1973) mentioned the O. leguminosarum was associated with Periconiella sp. and species of Microthyriaceae in their diagnosis and treated the genus in Schizothyriaceae.
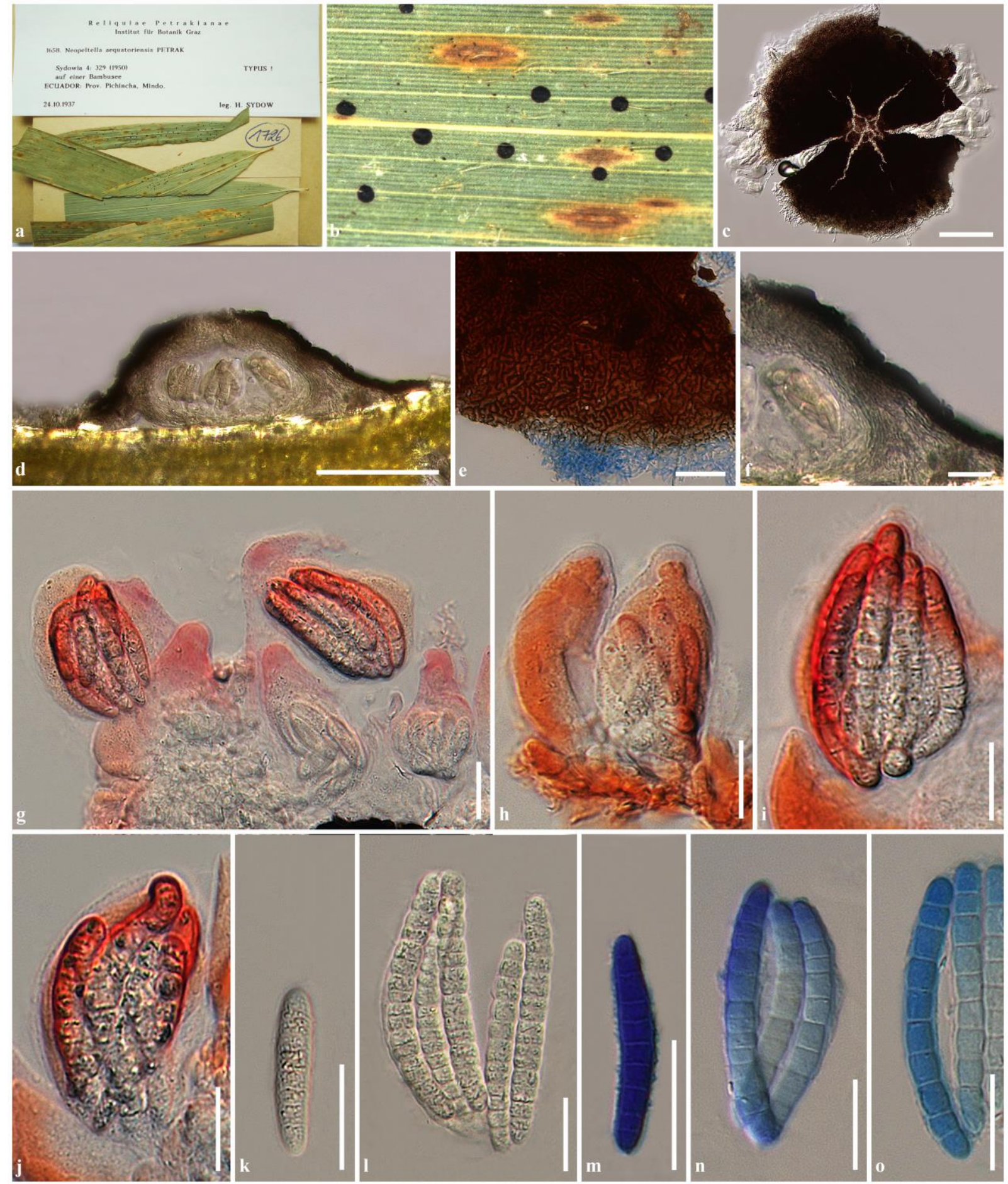

Fig. 13 - Neopeltella aequatoriensis (S-F10295, type). a. Label and specimens from S. b. Appearance of ascomata on the host surface. c. Squash of ascoma visualized under the compound microscope. d. Section through ascoma. e. Peridium structure visualized from above. f. Section through peridium. $\mathrm{g}-\mathrm{j}$. Asci stained in congo red. $\mathrm{k}, \mathrm{l}$. Ascospores. $\mathrm{m}-\mathrm{o}$. Ascospores stained in cotton blue. Scale bars: c, $d=100 \mu \mathrm{m}, \mathrm{e}-\mathrm{O}=20 \mu \mathrm{m}$. 
Orthobellus is a poorly understood genus, which lacks modern taxonomic description and molecular data. There are two species listed in Index Fungorum (2016) which lack sequence data in GenBank. Since the genus was introduced in 1973, no mycologist has studied on the genus. Eriksson and Hawksworth $(1985,1987)$ treated the genus in Schizothyriaceae and this was followed by Kirk et al. (2001, 2008), Lumbsch and Huhndorf (2010), Hyde et al. (2013) and Wijayawardene et al. (2014).
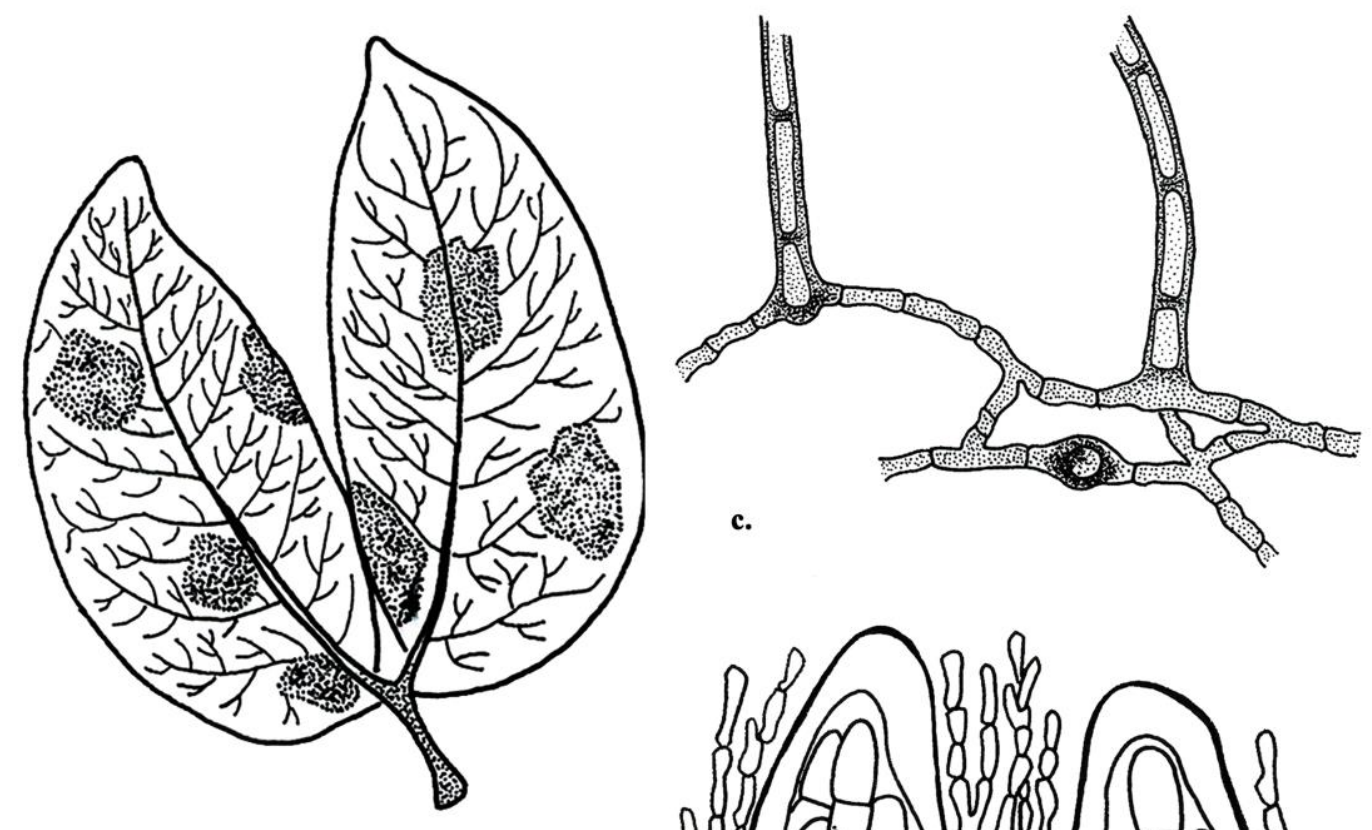

.
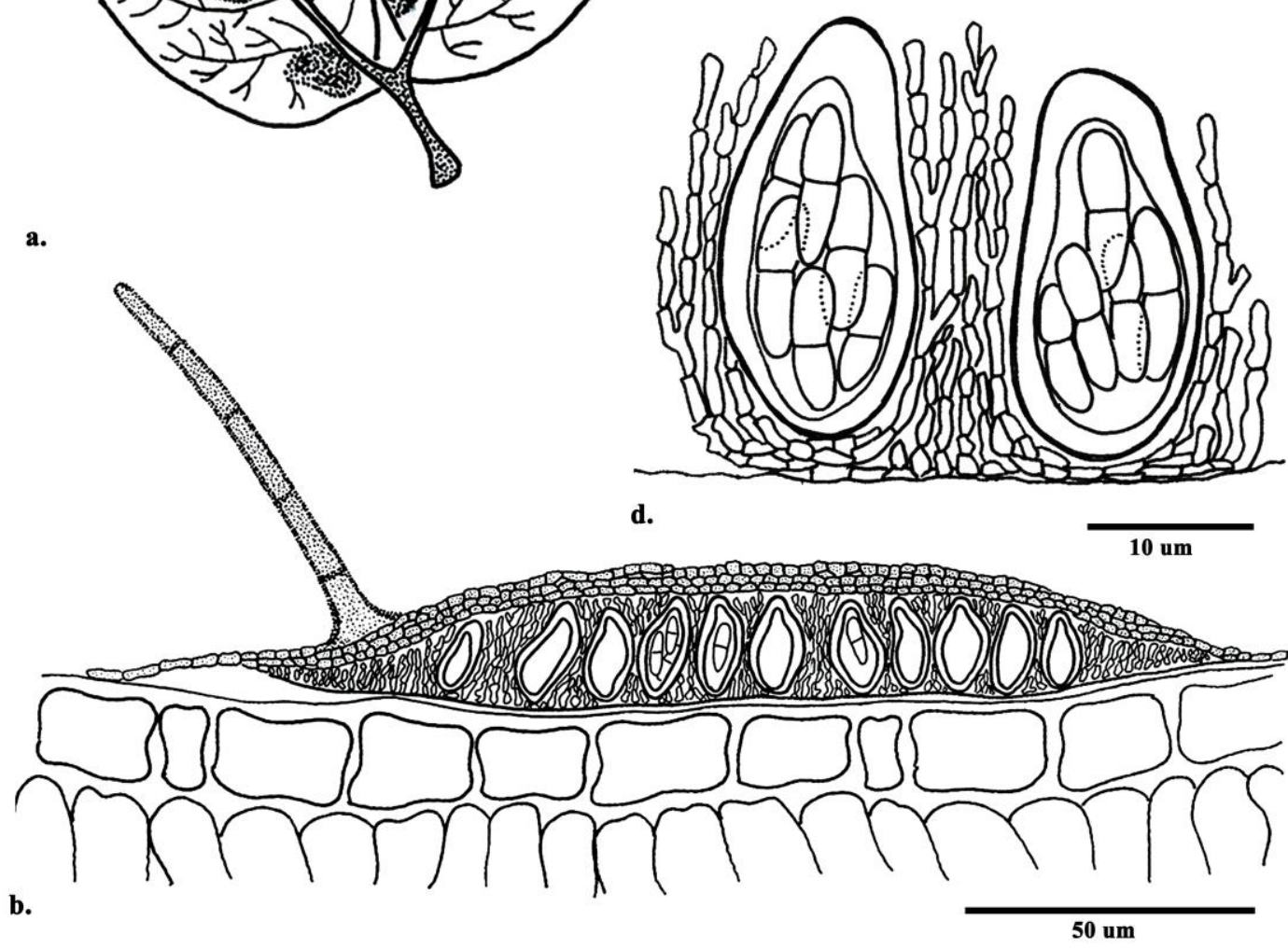

Fig. 14 - Orthobellus leguminosarum (redrawn from Silva et al. 1973, iconotype).

The type specimen of Orthobellus leguminosarum has been examined and is in poor condition. Dark tufting, hypophyllous colonies occurred on the host, but ascomata could not be found. However, we examined another epiphytic species on the host, which was similar to $O$. leguminosarum in having membranous, non-ostiolate ascomata and forming narrowly cellular pseudoparaphyses. Therefore, we introduce a new species, for which an illustration and description is provided. 
Orthobellus is similar to other genera in Schizothyriaceae in having membranous ascomata, and lacking ostioles, but the genus differs from other species in having narrowly anastomosing pseudoparaphyses and a developed peridium at the base. Genera in Schizothyriaceae form net-like, or paraphysoid-like filaments, and have a poorly-developed peridium at the base. Orthobellus has unique morphological characters which do not match any other epifoliar Dothideomycete taxa. Therefore, we tentatively place the genus in Dothideomycetes, genera incertae sedis, until recollection and molecular data is obtained to clarify its natural placement.
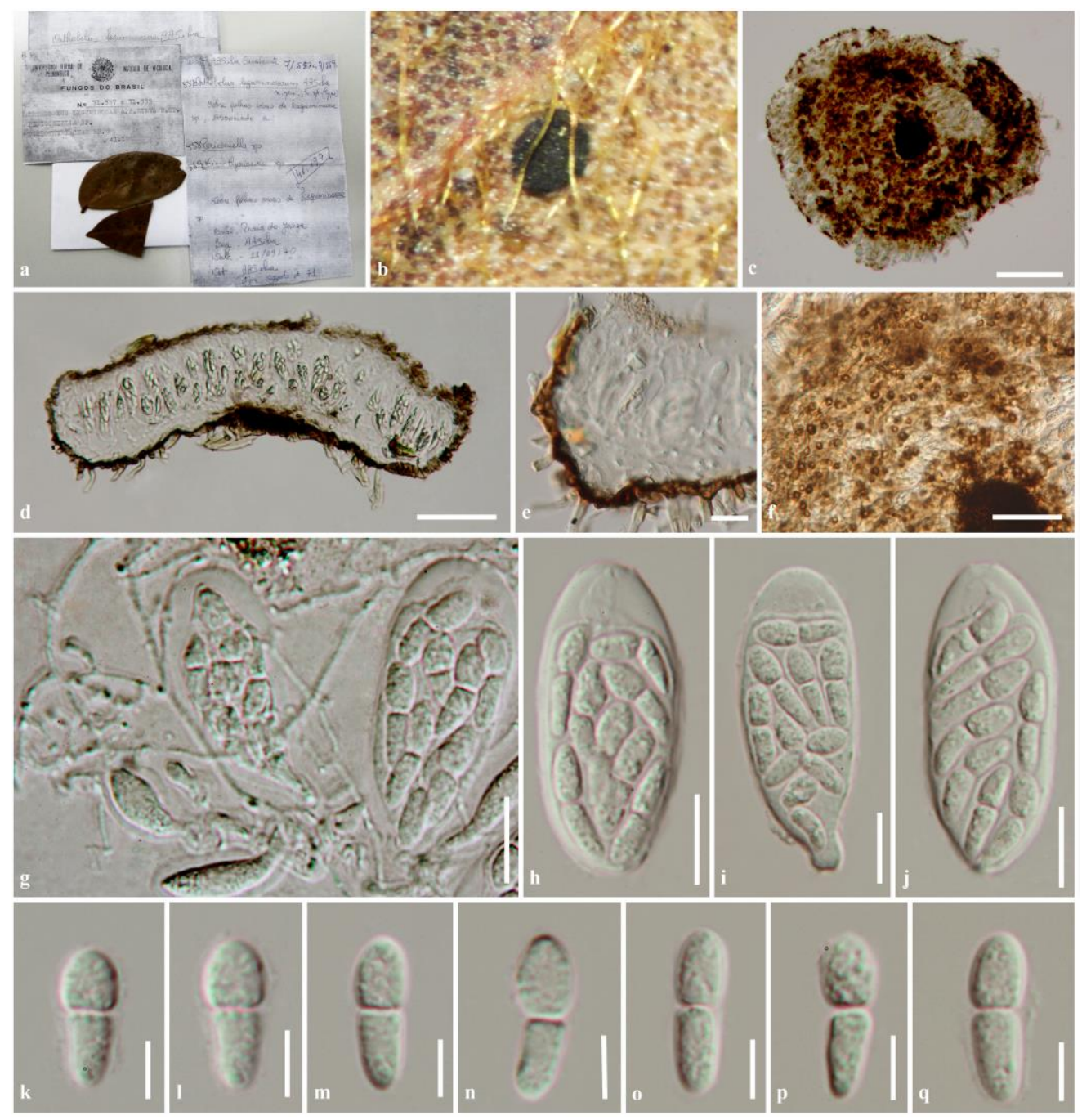

Fig. 15 - Orthobellus paraleguminosarum (URM 71557, type). a. Herbarium specimen from URM. b. Appearance of ascomata on the host surface. c. Ascoma visible under the compound microscope. d. Sections through ascoma. e. Section through peridium. f. Peridium structure visualize on top. g. Asci embedded in pseudoparaphyses. $\mathrm{h}-\mathrm{j}$. Asci. k-q. Ascospores. Scale bars: c, $\mathrm{d}=100 \mu \mathrm{m}, \mathrm{e}=20 \mu \mathrm{m}, \mathrm{f}-\mathrm{j}=10 \mu \mathrm{m}, \mathrm{k}-\mathrm{q}=5 \mu \mathrm{m}$.

Orthobellus paraleguminosarum Phookamsak \& Hyde K.D. sp. nov.

Fig. 15 IF551985

FoF 01955

Etymology: Para- (Gr.: beside, next to, resemble, towards), the epithet "Paraleguminosarum" refers to the resemblance to species Orthobellus leguminosarum.

Epiphytic on the lower surface of leaves of Leguminosae. Sexual morph: Ascomata 110 $150 \mu \mathrm{m}$ high, 400-530 $\mu \mathrm{m}$ diam., scattered, solitary, flattened, black, circular, superficial, quadrilateral, uni-loculate, glabrous, forming short, brown, aseptate hyphae at the base, membranous, with dark brown, dense, dots in hyphae at the central apex, lacking ostioles. Peridium 
4-12 $\mu \mathrm{m}$ wide, thin-walled, composed 1-2 layers of brown to dark brown cells, arranged in a textura angularis. Hamathecium composed of dense, $0.5-1.2 \mu \mathrm{m}$ wide, filamentous, cellular pseudoparaphyses, anastomosing among the asci. Asci $(34-) 35-43(-47) \times(13-) 15-17 \mu \mathrm{m}(\bar{x}=$ $38.9 \times 16.4 \mu \mathrm{m}, \mathrm{n}=25), 8$-spored, bitunicate, oblong to ellipsoidal, sessile to subsessile, apically rounded with well-developed ocular chamber. Ascospores $(10.5-) 11-13(-15) \times 3-5 \mu \mathrm{m}(\bar{x}=13 \times$ $4.4 \mu \mathrm{m}, \mathrm{n}=30$ ), overlapping irregularly bi- to tetra-seriate, hyaline, oblong to subclavate, 1 -septate, deeply constricted at the septum, thick and rough-walled, echinulate. Asexual morph: Undetermined.

Material examined - BRAZIL, Praia do yanga, on leaves of Leguminosae, 9 November 1970, A. A. Silva, URM 71557, type.

Notes -Orthobellus paraleguminosarum differs from $O$. leguminosarum and $O$. lauracearum in having glabrous ascomata while O. leguminosarum and O. lauracearum having setose ascomata (Batista et al. 1963, Silva et al. 1973).

\section{Acknowledgements}

We sincerely appreciate The Royal Golden Jubilee Ph. D. Program (PHD/0090/2551) under the Thailand Research Fund for financial support. Humidtropics, a CGIAR Research Program that aims to develop new opportunities for improved livelihoods in a sustainable environment and Mae Fah Luang University (grant for study Dothideomycetes No. 56101020032) are gracefully thanked for partial funding and laboratory works. KD Hyde acknowledges The Deanship of Scientific Research at King Saud University for funding this Prolific Research group (PRG-1436-09) and The Chinese Academy of Sciences, project number 2013T2S0030, for the award of Visiting Professorship for Senior International Scientists at Kunming Institute of Botany. Amy Y Rossman and the United States Department of Agriculture, Agricultural Research Service are sincerely thanked for loaning specimens and type information, and supervising this work. The curators from BPI, BR, PC, S, URM, W, YAM are thanked for loaning specimens and type information. Ausana Mapook, Carlos Llarena, Dong Qin Dai, Jie Chen, Mingkwan Doilom and Olivier Raspé are appreciated for taxonomic literature information and general assistance.

\section{References}

Ariyawansa HA, Hawksworth DL, Hyde KD, Jones EBG, Maharachchikumbura SSN, Manamgoda DS, Thambugala KM, Udayanga D, Camporesi E, Daranagama A, Jayawardena R, Liu JK, McKenzie EHC, Phookamsak R, Senanayake IC, Shivas RG, Tian Q, Xu JC 2014 Epitypification and neotypification: guidelines with appropriate and inappropriate examples. Fungal Diversity 69(1), 57-91.

Ariyawansa HA, Kang JC, Alias SA, Chukeatirote E, Hyde KD 2013 - Towards a natural classification of Dothideomycetes: The genera Dermatodothella, Dothideopsella, Grandigallia, Hysteropeltella and Gloeodiscus (Dothideomycetes incertae sedis). Phytotaxa 147(2), 35-47.

Barr ME 1979 - A classification of Loculoascomycetes. Mycologia 71, 935-957.

Barr ME 1987 - Prodromus to Class Loculoascomycetes. Amherst. University of Massachusetts, Massachusetts.

Batista AC 1959 - Monografia dos fungos Micropeltaceae. Publicações do Instituto de Micologia da Universidade do Recife. 56, 1-519.

Batista AC, Bezerra JL, Cavalcante WA, Maia HS 1963 - Mycerema e outros novos gêneros de Stomiopeltoideae, da familia Micropeltaceae. Publicações do Instituto de Micologia da Universidade do Recife. 392, 1-40.

Batista AC, Cavalcanti WA, Mello OB 1967 - Novos binomios da familia Micropeltaceae. Atas do Instituto de Micologia da Universidade do Recife 5, 453-462. 
Batzer JC, Arias MMD, Harrington TC, Gleason ML 2008 - Four species of Zygophiala (Schizothyriaceae, Capnodiales) are associated with the sooty blotch and flyspeck complex on apple. Mycologia 100(2), 246-258.

Batzer JC, Gleason ML, Harrington TC, Tiffany LH 2005 - Expansion of the sooty blotch and flyspeck complex on apples based on analysis of ribosomal DNA gene sequences and morphology. Mycologia 97(6), 1268-1286.

Crous PW, Braun U, Groenewald JZ 2007 - Mycosphaerella is polyphyletic. Studies in Mycology $58,1-32$.

Crous PW, Schoch CL, Hyde KD, Wood AR, Gueidan C, de Hoog GS, Groenewald JZ 2009 Phylogenetic lineages in the Capnodiales. Studies in Mycology 64, 17-47.

Dai DQ, Phookamsak R, Wijayawardene NN, Li WJ, Bhat DJ, Xu JC, Taylor JE, Hyde KD 2016 Bambusicolous fungi. Fungal Diversity (in press).

Desmazières JBHJ 1849 - Dix-septième notice sur les plantes cryptogames récemment découvertes en France. Annales des Sciences Naturelles Botanique. 11, 339-365.

Durbin RD, Davis LH, Snyder WC, Baker KF 1953 - The imperfect stage of Mycothyriella rubi, cause of flyspeck of apple. Phytopathology 43, 470-471.

Eriksson OE 1981 - The families of bitunicate ascomycetes. Opera Botanica 60, 1-220.

Eriksson OE, Hawksworth DL 1985 - Outline of the ascomycetes - 1985. Systema Ascomycetum $4,1-79$.

Eriksson OE, Hawksworth DL 1987 - Notes on ascomycete systematics. Nos 464-551. Systema Ascomycetum 6 (2), 237-258.

Farr DF, Rossman AY 2015 - Fungal Databases, Systematic Mycology and Microbiology Laboratory, ARS, USDA. Retrieved November to December 2015, from http://nt.arsgrin.gov/fungaldatabases/

Gao L, Zhang M, Zhao W, Hao L, Chen H, Zhang R, Batzer JC, Gleason ML, Sun G 2014 Molecular and morphological analysis reveals five new species of Zygophiala associated with flyspeck signs on plant hosts from China. PLoS ONE 9(10), e110717, Doi: 10.1371/journal.pone.0110717.

Gómez HD, Clavel M 1998 - Primer reporte del género Plochmopeltis Theiss. (Schizothyriaceae, Ascomycotina) para Cuba. Revista del Jardín Botánico Nacional Habana. 17-18, 137-138.

Hansford CG 1944 - Contribution towards the fungus flora of Uganda. VI. New records. Proceedings of the Linnean Society London. 156(2), 102-124.

Hansford CG 1945 - Contribution towards the fungus flora of Uganda. VII. New records and revisions. Proceedings of the Linnean Society London. 157, 20-41.

Hansford CG 1946 - Contributions towards the fungus flora of Uganda VIII. New records. Proceedings of the Linnean Society London. 157, 138-212.

Hansford CG 1947 - New or interesting tropical fungi. I. Proceedings of the Linnean Society London. 158(1), 28-50.

Hawksworth DL, Sutton BC, Ainsworth GC 1983 - Ainsworth \& Bisby's Dictionary of the Fungi. 7th Edition. 412 pp. UK, Kew; Commonwealth Mycological Institute.

Hino I, Katumoto K 1961 - Linopeltis, a new genus of the Micropeltaceae. Journal of Japanese Botany.

Holm L, Holm K 1978 - Some pteridicolous Ascomycetes. Botaniska Notiser. 131, 97-115.

Hongsanan S, Li YM, Liu JK, Hofmann T, Piepenbring M, Bhat DJ, Boonmee S, Doilom M, Singtripop C, Tian Q, Mapook A, Zeng XY, Bahkali AH, Xu JC, Mortimer PE, Wu XH, Yang JB, Hyde KD 2014 - Revision of genera in Asterinales. Fungal Diversity 68(1), $1-68$.

Hyde KD, Jones EBG, Liu JK, Ariyawansa HA, Boehm E, Boonmee S, Braun U, Chomnunti P, Crous PW, Dai DQ, Diederich P, Dissanayake A, Doilom M, Doveri F, Hongsanan S, Jayawardena R, Lawrey JD, Li YM, Liu YX, Lücking R, Monkai J, Muggia L, Nelsen M.P., Pang, K.L., Phookamsak, R., Senanayake, I.C., Shearer, C.A., Suetrong, S., Tanaka, K, Thambugala KM, Wijayawardene NN, Wikee S, Wu HX, Zhang Y, Hudson BA, Alias 
SA, Aptroot A, Bahkali AH, Bezerra JL, Bhat DJ, Camporesi E, Chukeatirote E, Gueidan C, Hawksworth DL, Hirayama K, Hoog SD, Kang JC, Knudsen K, Li WJ, Li XH, Liu ZY, Mapook A, McKenzie EHC, Miller AN, Mortimer PE, Phillips AJL, Raja HA, Scheuer C, Schumm F, Taylor JE, Tian Q, Tibpromma S, Wanasinghe DN, Wang Y, Xu JC, Yacharoen S, Yan JY, Zhang M 2013 - Families of Dothideomycetes. Fungal Diversity 63, $1-313$.

Hyde KD, McKenzie EHC, KoKo TW 2011 - Towards incorporating anamorphic fungi in a natural classification - checklist and notes for 2010. Mycosphere 2(1), 1-88.

Index Fungorum 2016 - http://www.indexfungorum.org/Names/Names.asp.

Jayasiri SC, Hyde KD, Ariyawansa HA, Bhat DJ, Buyck B, Cai L, Dai YC, Abd-Elsalam KA, Ertz D, Hidayat I, Jeewon R, Jones EBG, Bahkali AH, Karunarathna SC, Liu JK, Luangsa-ard JJ, Lumbsch HT, Maharachchikumbura SSN, McKenzie EHC, Moncalvo JM, GhobadNejhad M, Nilsson H, Pang KL, Pereira OL, Phillips AJL, Raspé O, Rollins AW, Romero AI, Etayo J, Selçuk F, Stephenson SL, Suetrong S, Taylor JE, Tsui CKM, Vizzini A, Abdel-Wahab MA, Wen TC, Boonmee S, Dai DQ, Daranagama DA, Dissanayake AJ, Ekanayaka AH, Fryar SC, Hongsanan S, Jayawardena RS, Li WJ, Perera RH, Phookamsak R, de Silva NI, Thambugala KM, Tian Q, Wijayawardene NN, Zhao RL, Zhao Q, Kang JC, Promputtha I 2015 - The Faces of Fungi database: fungal names linked with morphology, phylogeny and human impacts. Fungal Diversity 74(1), 3-18.

Kirk PM, Cannon PF, David JC, Stalpers JA 2001 - Ainsworth \& Bisby's dictionary of the fungi, $9^{\text {th }}$ edn, CABI, Wallingford.

Kirk PM, Cannon PF, Minter DW, Stalpers JA 2008 - Ainsworth \& Bisby’s dictionary of the fungi, $10^{\text {th }}$ edn. CABI, Wallingford.

Limber DP, Jenkins AE 1949 - Weedon's Myriangium on Sabal. Mycologia 41(5), 545-552.

Lumbsch HT, Huhndorf SM 2010 - Outline of Ascomycota-2009. Fieldiana Life and Earth Sciences 1, 1-60.

Ma Y, Zhang R, Sun G, Zhu H, Tang M, Batzer JC, Gleason ML 2010 - A new species of Zygophiala associated with the flyspeck complex on apple from China. Mycological Progress 9, 151-155.

Müller E, Farr ML 1971 - A new genus of the Schizothyriaceae from the Pacific north-west. Mycologia 63(5), 1080-1083.

Müller E, von Arx JA 1962 - Die Gattungen der didymosporen Pyrenomyceten. Beiträge zur Kryptogamenflora der Schweiz 11(2), 1-922.

Pande A 2008 - Ascomycetes of Peninsular India. Scientific Publishers (India).

Patouillard NT, de Lagerheim G 1895 - Champignons de l'Équateur (Pugillus V). Bulletin de la Société Mycologique de France. 11(4), 205-234.

Petrak F 1923 - Mykologische Notizen. V. Annales Mycologici. 21(1-2), 1-69.

Petrak F 1929 - Mykologische Notizen X. Nos. 601-700. Annales Mycologici 27 (5-6), 324-410.

Petrak F 1950a - Index of Fungi. 1936-1939. 1-117. UK, Kew; Commonwealth Mycological Institute.

Petrak F 1950b - Neopeltella n. gen., eine neue Gattung der Dictyopeltineen. Sydowia 4(1-6), 329-332.

Phookamsak R, Hyde KD 2015a - Fenestellaceae. Mycosphere 6(4), 402-413, Doi $10.5943 /$ mycosphere/6/4/2

Phookamsak R, Liu JK, McKenzie EHC, Manamgoda DS, Chatpapamon C, Ariyawansa HA, Thambugala KM, Dai DQ, Camporesi E, Chukeatirote E, Wijayawardene NN, Mortimer PE, Xu JC, Hyde KD 2014 - Revision of Phaeosphaeriaceae. Fungal Diversity 68, 159238.

Phookamsak R, Norphanphoun C, Tanaka K, Dai DQ, Luo ZL, Liu JK, Su HY, Bhat DJ, Bahkali AH, Mortimer PE, Xu JC 2015b - Towards a natural classification of Astrosphaeriella-like species; introducing Astrosphaeriellaceae and Pseudoastrosphaeriellaceae fam. nov. and Astrosphaeriellopsis, gen. nov. Fungal Diversity 74(1), 143-97. 
Raciborski M 1900 - Parasitische Algen und Pilze Java's. 3, 1-49.

Rehm H 1895 - Ascomycetes Exsiccati Fasc. 23. Hedwigia Beiblätter. 34, 159-165.

Rehm H 1909 - Ascomycetes novi. Annales Mycologici. 7(6), 531-542.

Rossman AY, Crous PW, Hyde KD, Hawksworth DL, Aptroot A, Bezerra JL, Bhat JD, Boehm E, Braun U, Boonmee S, Camporesi E, Chomnunti P, Dai DQ, D'souza MJ, Dissanayake A, Jones EBG, Groenewald JZ, Hernández-Restrepo M, Hongsanan S, Jaklitsch WM, Jayawardena R, Li WJ, Kirk PM, Lawrey JD, Mapook A, McKenzie EHC, Monkai J, Phillips AJL, Phookamsak R, Raja HA, Seifert KA, Senanayake IC, Slippers B, Suetrong S, Taylor JE, Thambugala KM, Tian Q, Tibpromma S, Wanasinghe DN, Wijayawardene NN, Wikee S, Woudenberg JHC, Wu HX, Yan J, Yang T, Zhang Y 2015 - Recommended names for pleomorphic genera in Dothideomycetes. IMA Fungus 6(2), 507-523.

Saccardo PA 1891 - Sylloge Fungorum 9, 1-1141.

Saccardo PA 1906 - Sylloge Fungorum 18, 1-839.

Saccardo PA 1928 - Sylloge fungorum omnium hucusque cognitorum. Vol. XXIV. Sectio II. Supplementum universale Pars X. Curante Alex Trotter. 705-1438.

Sawada K 1959 - Descriptive catalogue of Taiwan (Formosan) fungi. Part XI. Special Publication College of Agriculture National Taiwan University. 8, 1-268.

Silva AA, Cavalcante WA, Leal, FB 1973 - Um novo gênero da família Schizothyriaceae, em Leguminosae. Publicações do Instituto de Micologia da Universidade do Recife. 691, 1-16. Spegazzini C, 1888 - Fungi Guarinitici. Pugillus II. Anales de la Sociedad Científica Argentina. 26(1), 5-74.

Steven FL 1925 - Hawaiian fungi. Bulletin of the Bernice Bishop Museum 19, 1-189.

Sydow H 1927 - Fungi in itinere costaricense collecti. Annales Mycologici. 25(1-2), 1-160.

Sydow H, Sydow P 1917 - Beitrag zur Kenntniss der Pilzflora der Philippinen-Inseln. Annales Mycologici. 15(3-4), 165-268.

Theissen F 1912 - Fragmenta Brasilica. V nebst Besprechung einiger palaeotropischer Microthyriaceen. Annales Mycologici 10 (1), 159-204.

Theissen F 1914 - Annotacoes à Mycoflora Brasileira. Brotéria Série Botânica. 12, 13-31.

Toro RA 1927 - Fungi of Santo Domingo - I. Mycologia 19 (2), 66-85.

Ulloa M, Hanlin RT 2000 - Illustrated dictionary of mycology. American Phytopathological Society (APS Press).

von Arx JA 1959a - Ein beitrag zur kenntnis der fliegenfleckenpilze. Proceedings van de Koninklijke Nederlandse Akademie van Wetenschappen, Section C 62, 333-340.

von Arx JA 1959b - Über die Ascomycetengattung Plochmopeltis Theiss. Persoonia 1, 1-5.

von Arx JA, Müller E 1975 - A re-evaluation of the bitunicate ascomycetes with keys to families and genera. Studies in Mycology 9: 1-159.

von Höhnel FXR 1909a - Fragmente zur Mykologie (VI. Mitteilung, Nr. 182 bis 288). Sitzungsberichte der Kaiserlichen Akademie der Wissenschaften in Wien MathematischNaturwissenschaftliche Classe, Abt. 1 118, 275-452.

von Höhnel FXR 1909b - Fragmente zur Mykologie: VIII. Mitteilung (Nr. 354 bis 406). Sitzungsberichte der Kaiserlichen Akademie der Wissenschaften Math.-naturw. Klasse Abt. I. 118, 1157-1246.

von Höhnel FXR 1912 - Fragmente zur Mykologie (XIV. Mitteilung, Nr. 719 bis 792) [Mycological notes. 14th communication, nos 719 to 792]. Sitzungsberichte der Kaiserlichen Akademie der Wissenschaften in Wien Mathematisch-Naturwissenschaftliche Classe, Abt. 1 121, 339-424.

von Höhnel FXR 1917 - Über die Trichothyriaceen. Berichte der Deutschen Botanischen Gesellschaft 35, 411-416.

Wijayawardene NN, Crous PW, Kirk PM, Hawksworth DL, Boonmee S, Braun U, Dai DQ, D'souza MJ, Diederich P, Dissanayake A, Doilom M, Hongsanan S, Jones EBG, Groenewald JZ, Jayawardena R, Lawrey JD, Liu JK, Lücking R, Madrid H, Manamgoda DS, Muggia L, Nelsen MP, Phookamsak R, Suetrong S, Tanaka K, Thambugala KM, 
Wanasinghe DN, Wikee S, Zhang Y, Aptroot A, Ariyawansa HA, Bahkali AH, Bhat DJ, Gueidan C, Chomnunti P, De Hoog GS, Knudsen K, Li WJ, McKenzie EHC, Miller AN, Phillips AJL, Piątek M, Raja HA, Shivas RS, Slippers B, Taylor JE, Tian Q, Wang Y, Woudenberg JHC, Cai L, Jaklitsch WM, Hyde KD 2014 - Naming and outline of Dothideomycetes-2014 including proposals for the protection or suppression of generic names. Fungal Diversity 69, 1-55.

Wijayawardene NN, McKenzie EHC, Hyde KD 2012 - Towards incorporating anamorphic fungi in a natural classification - checklist and notes for 2011. Mycosphere 3(2), 157-228, Doi 10.5943/mycosphere/3/2/5.

Wu HX, Schoch CL, Boonmee S, Bahkali AH, Chomnunti P, Hyde KD 2011 - A reappraisal of Microthyriaceae. Fungal Diversity 51(1), 189-248.

Yacharoen S, Tian Q, Chomnunti P, Boonmee S, Chukeatirote E, Bhat JD, Hyde KD 2015 Patellariaceae revisited. Mycosphere 6(3), 290-326.

Yang HL, Sun GY, Batzer JC, Crous PW, Groenewald JZ, Gleason ML 2010 - Novel fungal genera and species associated with the sooty blotch and flyspeck complex on apple in China and USA. Persoonia 24, 29-37.

Zimmermann A 1902 - Über einige an tropischen Kulturpflanzen beobachtete Pilze. II. Centralblatt für Bakteriologie und Parasitenkunde. 8, 181-184. 